\title{
LA PRENDA SIN DESPLAZAMIENTO DE VALORES DESMATERIALIZADOS O EMITIDOS SIN IMPRESIÓN FÍSICA DEL TÍTULO QUE LOS EVIDENCIE*
}

\author{
ASSET PLEADGES ON UNMATERIALIZED SECURITIES OR ISSUED \\ WITHOUT ANY PHYSICAL DOCUMENT THAT CERTIFICATES \\ THEM
}

\section{ALEJANDRo GUZMÁN BRITO**}

\begin{abstract}
RESUMEN: La nueva "Ley de prenda sin desplazamiento", contenida en el artículo 14 de la Ley No 20.190, autoriza la pignoración de "valores emitidos sin impresión física del título que los evidencie", que en otro lenguaje se llaman "valores desmaterializados". El artículo indaga los principales extremos del concepto de tales valores y expone el régimen de su pignoración, que no solo deriva del artículo 8 de la nueva "Ley de prenda sin desplazamiento", pues también lo conciernen ciertas disposiciones de la Ley No 18.876, de 1989, sobre sociedades de depósito de valores y aun de otros cuerpos legales.
\end{abstract}

Palabras clave: Prenda sin desplazamiento, Valores desmaterializados, Prenda de valores desmaterializados.

ABSTRACT: The new disposition regarding "asset pleadges" that is contained in article 14 of Law 20.190 Authorizes to take a mortage on securities created without any physical document that certificates the issue of such value wich often relieves the name of "unmetrialized securities". This article investigates the different uses of that particular securities. It explains the procedure of unmaterial securities' mortagages that is not only a product of the law 18.876 but also a product of other legal texts, such as the Deposit securities companys act.

Key words: Asset pleadges, unmaterialized securities, pleadge on unmaterialize values.

\section{INTRODUCCIÓN}

La nueva "Ley de prenda sin desplazamiento", contenida en el artículo 14 de la Ley No 20.190, entre los objetos pignorables al amparo de sus disposiciones considera los "valores emitidos sin impresión física del título que los evidencie" (artículo ${ }^{1}$ ). La

\footnotetext{
* Este trabajo hace parte del proyecto patrocinado por FONDECYT bajo el número 1095068.

** Doctor en Derecho por la Universidad de Navarra, España; Profesor titular de Derecho romano de la Facultad de Derecho de la Pontificia Universidad Católica de Valparaíso. Dirección postal: Facultad de Derecho, Pontificia Universidad Católica de Valparaíso, Avenida Brasil 2950, Valparaíso, Chile. Correo electrónico: aguzman@ucv.cl

${ }^{1}$ Cfr., en el mismo sentido, el artículo 19 del Reglamento del Registro de Prendas sin Desplazamiento, contenido en el Decreto supremo $N^{\circ} 722$ del Ministerio de Justicia, publicado en el $D O$. de 23 de octubre de 2010 .
} 
norma hace aplicación específica de la generalidad conceptual acerca de los objetos pignorables con que fueron redactados los artículos 1 y 5 de la misma ley a que pertenece el artículo 14, en cuanto autorizan imponer tal gravamen a toda clase de cosas incorporales ${ }^{2}$. Ahora bien, en la medida en que los valores emitidos sin impresión física del título que los evidencie consisten en un derecho de crédito, vale decir, en una cosa incorporal, su pignoración sin desplazamiento ya había quedado consentida por los mencionados artículos. Por consiguiente, otra hubo de ser la finalidad del artículo 8; y podemos adelantar que ella, en efecto, consistió en prescribir cierta anotación que, en principio, de otro modo no hubiera podido ser exigida.

Destinamos el presente trabajo a examinar el régimen de la pignoración de los valores emitidos sin impresión física del título que los evidencie, para lo cual, sin embargo, resulta previo estudiar en general la noción de tales valores, con independencia de su pignoración.

\section{EL CONCEPTO DE "VALOR EMITIDO SIN IMPRESIÓN FÍSICA DEL TÍTULO QUE LO EVIDENCIE" O "TÍTULO QUE SE EMITE DESMATERIALIZADO"}

\section{EL DEPÓSITO DE VALORES}

En la legislación chilena ${ }^{3}$, la denominación de "valor emitido sin impresión física del título que lo evidencie" es sinónima de "valor que se emite desmaterializado" ${ }^{4} \mathrm{o}$ "valor desmaterializado". Su esencia radica en que el valor (acción, bono, "debenture", pagaré de empresa, opción a la compra y venta de acciones, cuota de un fondo mutuo, plan de ahorro, efecto de comercio, etcétera) no se corporifica o materializa en un título o documento de papel, cartulina, cartón u otro soporte físico fabricado con celulosa o materia semejante, que suele ser denominado "lámina”, el cual puede circular por entrega o traspaso material de mano a mano, sino que consiste y consta en una anotación o asiento de la titularidad y otras circunstancias del valor en cierto registro, de modo que la circulación opera merced a nuevas anotaciones o asientos a nombre de otros titulares 5 .

\footnotetext{
2 Dice el artículo 1: "El contrato de prenda sin desplazamiento tiene por objeto constituir una garantía sobre una o varias cosas corporales o incorporales muebles [...]"; y el artículo 5: "Podrá constituirse prenda sobre todo tipo de cosas corporales o incorporales muebles [...]".

${ }^{3}$ En tema de valores desmaterializados conviene andar con cuidado a la hora de usar la doctrina extranjera, debido a la gran variedad de sistemas, modelos y técnicas empleados, que no permite una fácil y natural aplicación a la institucionalidad nacional, por lo demás no muy avanzada ni desarrollada. Acerca de los sistemas de desmaterialización en diversas legislaciones europeas, véanse las abundantes noticias que ofrece CORTÉS GARCíA, Eduardo (2002), pp. 47 ss., 77 ss. Véase también CABALLERO GERMAIN, Guillermo (2010), pp. 34 ss.

${ }^{4}$ Véase el artículo 131 letra h) inciso 50 de la Ley $\mathrm{N}^{\circ} 18.045$ de mercado de valores, en DO. 22 de octubre de 1981; pero véase la nota siguiente.

5 Obsérvese, en consecuencia, que las expresiones "título" y "asiento en cuenta" son opuestas; de modo que no se trata de que el título de un valor consista en su asiento en cuenta. Cuando un valor se asienta en cuenta, pues, no tiene título. La legislación a veces confunde los términos, como en el artículo 131 letra h) inciso $5^{\circ}$ de la Ley No 18.045: "Los pagarés, letras u otros títulos de crédito que se emitan desmaterializados [...]", porque la expresión "títulos de crédito que se emitan desmaterializados" es contradictoria; lo que se emite desmaterializado es el valor.
} 
Está expresamente dicho en el artículo 14 de la Ley No 18.876 que la ausencia de título material de un valor no afecta su calidad de valor definida por el 3 de la Ley No 18.045: Sobre mercado de valores ${ }^{6}$.

La base legal de esta modalidad de emisión de valores está precisamente en la Ley No 18.876, de 1989, que: Establece el marco legal para la constitución y operación de entidades privadas de depósito y custodia de valores 7 . Ese cuerpo legal creó un género de sociedades anónimas denominadas "empresas de depósito o custodia de valores", cuya función es precisamente recibir en guarda valores de oferta pública inscritos en el Registro de Valores a cargo la Superintendencia de Valores y Seguros, o emitidos por los bancos, incluido el Central de Chile, o emitidos o garantizados por el Estado y, en general, cualquier otro valor que autorice la Superintendencia mediante norma de carácter general (artículo 1). En la actualidad existe una única empresa del tipo dicho, que se llama Depósito Central de Valores S.A., creada en 1993.

El depósito de valores puede ser ejecutado únicamente por los siguientes profesionales, personas o instituciones: el Fisco, la Corporación de Fomento de la Producción, los agentes de valores, los corredores de bolsa, las bolsas de valores, los bancos, las sociedades financieras y demás instituciones de crédito, las administradoras de fondos mutuos, las administradoras de fondos de pensiones, las compañías de seguros y de reaseguros, las administradoras de fondos de inversión, las administradoras de fondos para la vivienda y las sociedades administradoras de sistemas de compensación y liquidación de instrumentos (artículo 2). Por consiguiente, los entes no incluidos en la precedente enumeración, y notablemente las personas naturales y las sociedades, corporaciones y fundaciones particulares, que suelen ser dueñas de valores, no los pueden entregar ellas mismas en guarda a una sociedad de custodia, más que por intermedio de algún profesional habilitado, por ejemplo, un corredor de bolsa o un banco, a los cuales aquellos deben previamente traspasarlos, para que sean ellos los depositantes en nombre de sus dueños.

Este depósito consiste en un contrato que se perfecciona mediante la entrega material de los títulos de los valores a la empresa de custodia por el depositante, mediante las formalidades propias de la transferencia de dominio, según sea la naturaleza del título de que se trate (artículo 3 inciso $\left.1^{\circ}\right)^{8}$. La empresa tiene el deber de

\footnotetext{
${ }^{6}$ Artículo 14 de la Ley No 18.876: "La no emisión de título no afecta la calidad de valor para los efectos del Art. $3^{\circ}$ de la ley $N^{\circ}$ 18.045". El artículo 3 de la Ley No 18.045, por su lado, dice: "Para los efectos de esta ley, se entenderá por valores cualesquiera titulos transferibles incluyendo acciones, opciones a la compra y venta de acciones, bonos, debentures, cuotas de fondos mutuos, planes de ahorro, efectos de comercio y, en general, todo título de crédito o inversión. [...]".

7 DO. de 21 de diciembre de 1989. Véase el Decreto supremo No 734, del Ministerio de Hacienda, que aprueba el Reglamento de la Ley No 18.876 sobre depósitos de valores, publicado en el $D O$. de 30 de noviembre de 1991.

${ }^{8}$ Pero esta transferencia de dominio no produce efectos absolutos. Ante el depositante, la empresa depositaria es mera tenedora, de modo que aquel es dueño y poseedor de los valores. Así lo dice el segmento primero del artículo 5: "En las relaciones entre la empresa y el depositante, este es el propietario de los valores depositados a su nombre". Frente al emisor de los valores y a terceros, la empresa es dueña de los valores, como expresa el segundo segmento del artículo 5: "Ante el emisor de los valores y terceros, salvo las excepciones que se contemplan en esta ley, la empresa es considerada dueña de los valores que mantiene en depósito, lo que no significa que el depositante o su mandante, en su caso, dejen de tener el dominio de los valores depositados, para el ejercicio de los derechos políticos y patrimoniales, cuando corresponda".
} 
registrar los títulos recibidos en una cuenta individual a nombre de cada depositante (ibíd. $)^{9}$.

\section{LA DESMATERIALIZACIÓN DE VALORES}

a) Es en este marco general que la misma Ley No 18.876 autoriza la prescindencia del título físico de un valor y su sustitución por la mera anotación del mismo valor en una cuenta, que no necesariamente es manuscrita y puede ser digitalizada por medios electrónicos, a nombre del que sea su titular. Por eso la operación reemplazante de la emisión del título se llama "anotación en cuenta" y también "desmaterialización". A su respecto, el artículo 11 de la Ley No 18.876 expresa: "La empresa [sc. de depósito] y el respectivo emisor [sc. del valor] podrán acordar, respecto de valores en depósito o susceptibles de ser depositados, que el emisor no estará obligado a emitir titulos, sino a llevar en sus registros un sistema de anotaciones en cuenta, en favor de la respectiva empresa. La no emisión de título no afecta la calidad de valor para los efectos del Art. $3^{\circ}$ de la ley $N^{\circ}$ 18.045./ [Inciso 2०] Adoptado el acuerdo antes referido entre la empresa y un emisor banco o sociedad financiera, se entenderá satisfecha la necesidad de emisión y entrega material de las letras de crédito hipotecario que se originen con motivo de la celebración de los contratos de mutuos hipotecarios a que se refiere el Titulo XIII de la Ley General de Bancos.I [Inciso 30] Mediante norma de carácter general, la Superintendencia establecerá los requisitos minimos que deberá cumplir el sistema de anotaciones en cuenta y establecerá los casos y condiciones en que procederá la emisión de los títulos representativos de los valores, a petición de los interesados y siempre que con ello no se cause perjuicio al depositario o a sus mandantes, en su caso".

De acuerdo con esta norma, pues, el régimen de valores desmaterializados no es autónomo, en el sentido de que el emisor de cierto valor pueda decidir unilateralmente su desmaterialización; y resulta menester que esta sea acordada entre el emisor y una empresa de depósito de valores, de aquellas regidas por la Ley No 18.876, como lo expresa el inciso $1^{\circ}$ de su artículo 11: "La empresa [sc. de depósito de valores] y el respectivo emisor [sc. del valor] podrán acordar [...] que el emisor no estará obligado a emitir titulos, sino a llevar en sus registros un sistema de anotaciones en cuenta".

Este régimen que unía la desmaterialización al depósito, sin el cual, por ende, aquella no podía existir, recibió posteriores excepciones, entre las cuales cabe destacar dos:

i) Respecto de las acciones de sociedades anónimas abiertas, previa autorización de la Superintendencia de Valores y Seguros. Al punto se refiere el inciso $4^{\circ}$ del artículo

\footnotetext{
${ }^{9}$ Artículo 3: "El contrato de depósito se perfecciona mediante la entrega de los valores a la empresa, la que los registrará en la cuenta que corresponda, de las que mantenga el depositante respectivo". Esta cuenta aparece regulada en el artículo 4: "La empresa de depósito llevará una cuenta individual para cada depositante, en la cual registrará, en item separados, cada clase de valores homogéneos que aquél mantenga en depósito. Para los efectos de esta ley se entienden como valores homogéneos los que sean idénticos en cuanto a tipo, especie, clase, serie y emisor./ [Inciso $2^{\circ}$ ] Los valores que sean gravados con derechos reales o queden sujetos a embargo o medida precautoria, serán registrados en item separados en la cuenta del respectivo depositante, y no se les considerará homogéneos respecto de los demás de su mismo tipo, especie, clase, serie y emisor".
} 
12 en la Ley No 18.046: Sobre sociedades anónimas ${ }^{10}$, modificado por el artículo 2 No 7 letra b) de la Ley No 20.382, de 200911; el cual reza así: "La Superintendencia podrá autorizar a las sociedades anónimas abiertas, para establecer sistemas que sustituyan la obligación de emitir titulos o que simplifiquen en casos calificados la forma de efectuar las transferencias de acciones, siempre que dichos sistemas resguarden debidamente los derechos de los accionistas". La frase "obligación de emitir títulos" alude a la de emitir títulos físicos, o sea, en papel u otra materia análoga. Ahora bien, la norma no indica por cuál "sistema" se sustituye la emisión de títulos físicos; pero evidentemente tiene en mente la anotación del valor en cuenta, o sea, la desmaterialización. Así que, como se aprecia, supuesta una autorización de la Superintendencia, la emisión desmaterializada es unilateral de parte de la sociedad anónima abierta; vale decir, no merced a un contrato con una sociedad de depósito de valores, en los términos del artículo 11 de la Ley No 18.876. Lo cual no significa que la sociedad emisora no pueda depositar los valores ya unilateralmente emitidos en forma desmaterializada en una sociedad de depósito, para que se sometan al régimen a que se someten los emitidos de aquella manera previo contrato con la misma sociedad.

ii) La emisión de bonos y otros valores representativos de deuda pública que haga circular el Estado. El tema aparece regulado por artículo 47 bis del Decreto-ley No 1.263 Orgánico de la administración financiera del Estado ${ }^{12}$, que fue introducido por el artículo 1 de la Ley No 19.908, de 200313. Dice: "En la emisión de bonos y otros valores representativos de deuda pública que emita el Estado, el Ministerio de Hacienda, mediante decreto supremo cumplido bajo la fórmula 'Por orden del Presidente de la República', podrá disponer que tales bonos o valores sean emitidos sin la obligación de imprimir títulos o láminas físicas que evidencien la deuda pública correspondiente. El decreto supremo señalado precedentemente deberá indicar, para una o más emisiones determinadas, o en general, para todas las emisiones, las reglas, requisitos y demás modalidades necesarias para hacer valer los derechos emanados de los bonos o valores emitidos en la forma antes señalada, incluyendo el procedimiento requerido para transferirlos./ [Inciso 20] En caso que los bonos o valores se emitan en la forma señalada en el inciso anterior, la suscripción por el Tesorero General de la República y la refrendación del Contralor General de la República, exigidas en los artículos 45 y 46 precedentes, deberá efectuarse en una réplica o simil de los bonos o valores emitidos, quedando de esta forma y para todos los efectos legales, autorizada y refrendada la totalidad de los bonos o valores que integran la serie correspondientemente emitida y cuyos términos y condiciones serán idénticos a dicha réplica. / [Inciso 30] De la misma manera, tratándose de emisiones de bonos y valores efectuadas en la forma establecida en los incisos precedentes, el emisor deberá mantener un registro de anotaciones en cuenta a favor de los tenedores de los correspondientes valores representativos de la deuda pública. La mantención del mencionado registro podrá ser contratada con un tercero, en la forma que indique el decreto supremo a que se refiere el inciso primero".

\footnotetext{
${ }^{10}$ DO. de 22 de octubre de 1981.

${ }^{11}$ DO. de 20 de octubre de 2009.

12 DO. 28 de noviembre de 1975 .
} 
Así que el Estado, por decisión unilateral suya, puede emitir desmaterializadamente bonos y otros valores representativos de deuda pública. Tal decisión se manifiesta en un decreto supremo del Ministerio de Hacienda, dictado bajo la fórmula "Por orden del presidente de la República”. El inciso $3^{\circ}$ ordena al emisor, vale decir, al Estado, mantener un registro de anotaciones en cuenta a favor de los tenedores de los valores de deuda pública. Sin embargo, permite que la gestión del registro pueda ser contratada con un tercero, en la forma que indique el decreto supremo que funda la emisión. Es claro que el inciso $3^{\circ}$ dirige su mente principal, pero no exclusivamente, a las sociedades de depósito de valores.

b) A salvo estas excepciones ${ }^{14}$, pues, la emisión desmaterializada de valores debe ser consecuencia de un contrato entre un emisor y una empresa de custodia de valores, como expresa la frase inicial del inciso $1^{\circ}$ del artículo 11 de la Ley No 18.876. Tal inciso contrapone la obligación del emisor en orden a emitir títulos a la obligación del mismo en orden a llevar en sus registros un sistema de anotaciones en cuenta en favor de la respectiva empresa de custodia, que es en lo que la desmaterialización consiste. Ahora bien, al no haber emisión física de títulos, no puede haber entrega material de los mismos a la empresa de custodia, en función de perfeccionar el depósito de los valores en ella; pero este se perfecciona igualmente si el emisor anota en la cuenta de la empresa los valores depositados en ella. Puesto que el inciso $1^{\text {o }}$ del artículo 3 de la misma ley, antes visto $^{15}$, obliga a la empresa de custodia a registrar en una cuenta del depositante los títulos que este le depósito, en realidad debe haber un doble asentamiento en cuenta:

${ }^{13}$ DO. de 3 de octubre de 2003.

${ }^{14}$ No hay excepción en el régimen establecido por las adiciones que se introdujeron al artículo 3 transitorio del Decreto-ley No 3.500, de 1980: que establece un nuevo sistema de pensiones, por el artículo 5 No 5 letra b) de la Ley No 20.190, en tema de bono de reconocimiento previsional, creado por aquel decretoley, con la reforma, ahora puede ser emitido tanto en forma documental como desmaterializada. La nuevas norma somete esta última figura a la modalidad de un previo contrato con alguna sociedad de custodia, sentido en el cual, como decimos, no se innova en el régimen del artículo 11 de la Ley No 18.876. El íntegro artículo 3 transitorio del Decreto-ley No 3.500 reza así: "[Inciso $1^{\circ}$ original] Las instituciones de previsión del régimen antiguo emitirán un título de deuda expresado en dinero que se denominará Bono de Reconocimiento y será representativo de los periodos de cotizaciones que registren en ellas los imponentes que se incorporen al Sistema que establece esta ley./ [Inciso 2o nuevo] El Bono de Reconocimiento podrá emitirse en forma material, mediante un documento que cuente con las caracteristicas necesarias para impedir su falsificación, o desmaterializadamente; esto es, sin que sea necesaria la impresión de una lámina física en la que conste el Bono respectivo, no afectándose por ello la calidad jurídica ni la naturaleza de los Bonos. [Inciso $3^{\text {o }}$ nuevo] Los Bonos que se emitan bajo la modalidad desmaterializada deberán depositarse en una empresa de depósito de valores autorizada por la ley $N^{o}$ 18.876. Para estos efectos, las instituciones de previsión emisoras deberán acordar con una empresa de depósito de valores autorizada por la citada ley, que no emitirán Bonos en forma material sino que llevarán en sus registros un sistema de anotaciones en cuenta a favor de la empresa, y que esta se encargará de llevar los registros de los tenedores de los Bonos de Reconocimiento. Bajo el mismo acuerdo y condiciones, se podrá convenir la desmaterialización de los Bonos de Reconocimiento emitidos originalmente de forma material. La impresión física de un documento en el que conste el Bono de Reconocimiento solo será procedente en los casos en que esté autorizada por la ley $N^{o} 18.876$ o por las normas de la Superintendencia de Valores y Seguros. Dicha impresión deberá contar con las características necesarias para impedir su falsificación y su costo será de cargo del requirente./ [Inciso $4^{\circ}$ original] Se entiende por instituciones de previsión del régimen antiguo, aquéllas existentes a la fecha de publicación de esta ley".

15 Véase la nota 9. 
uno, por parte del emisor con respecto a los valores traspasados en depósito; y otro, por parte de la empresa de custodia con respecto a los valores recibidos en depósito; y se supone que ambos deben coincidir completamente ${ }^{16}$.

El contrato puede recaer bien sobre valores en depósito, bien sobre valores susceptibles de ser depositados (inciso $1^{\circ}$ del artículo 11 ). El primer caso atañe a valores ya depositados merced a una entrega de sus títulos físicos, así que la operación contractual tiene el sentido de sustituir la actual tenencia material de los títulos por su anotación en cuenta (lo que obliga a destruir los títulos materiales antes depositados); pero también puede suponer la conservación de la tenencia material de los títulos previamente depositados, y consistir en el reemplazo por anotaciones en cuenta cuando en el futuro tengan lugar nuevos movimientos concernientes a esos títulos. El segundo caso atañe a valores aun no depositados de manera alguna, así que se trata de sustituir sin más la entrega material de títulos por el asiento en cuenta, lo cual principalmente acaece cuando hay una emisión de nuevos valores que, por ende, nunca antes fueron depositados; así que nace, por así decirlo, desmaterializada.

c) El inciso $3^{\circ}$ del artículo 11 de la Ley No 18.876 confiere a la Superintendencia de Valores y Seguros el poder de establecer una norma de carácter general concerniente a los requisitos mínimos que deberá cumplir el sistema de anotaciones en cuenta y a los casos y condiciones en que procederá la emisión de los títulos representativos de los valores, a petición de los interesados. Con base en este poder, la Superintendencia tiene emitidas dos "Normas de carácter general", la No 77, de 20 de enero de 1998, referida a los requisitos mínimos del sistema de anotaciones en cuenta; y la No 105, de 16 de enero de 2001, concerniente a los casos y condiciones en que procederá la emisión de los títulos representativos de valores.

\section{LA PIGNORACIÓN SIN DESPLAZAMIENTO DE LOS VALORES DESMATERIALIZADOS EN GENERAL}

\section{TIPOS PRENDARIOS APLICABLES A LOS VALORES}

Los valores depositados en una empresa de custodia merced a la entrega de sus títulos pueden ser objeto de prenda entre otros gravámenes reales. A ellos se refiere sin discusión el inciso $1^{\circ}$ del artículo 14 de la Ley No 18.876, de 1989: "El depositante [sc. de valores] puede constituir prendas y derechos reales sobre los valores que tenga depositados, en los mismos casos en que podría hacerlo si no estuvieren en depósito". De acuerdo con él, un valor depositado es pignorable únicamente si era pignorable sin estar depositado. A la fecha de emisión de la ley, ella pudo pensar en las siguientes prendas i) civil y

\footnotetext{
16 Esta estructura recuerda poderosamente a la expensilatio o transscriptio nominum del Derecho romano clásico. El negocio consistía en la anotación de una suma de dinero como expendida (expensa) o como recibida (accepta) en el "libro de ingresos y egresos" (codex accepti et expensi) de un banquero, sin que la anotación obedeciera a una operación real de entrega o recepción de dinero físico; así que el negocio se perfeccionaba litteris, no re. La anotación como pecunia expensilata erigía un crédito a favor del banquero contra su cliente anotado; y la anotación como pecunia acceptilata, un crédito contra el banquero a favor de su cliente. Sobre la figura, véase: GUZMÁN BRITO, Alejandro (2004), II, pp. 99-103.
} 
mercantil con desplazamiento; ii) a favor de los bancos regida por la Ley No 4.287, de 1928; y iii) sin desplazamiento regida por la Ley No 18.112 de $1982^{17}$, porque cada uno de tales gravámenes podía ser impuesta a valores aun en el caso de no haber sido depositados sus títulos, de modo de cumplir con la regla del segmento final del inciso antes transcrito.

Ahora bien, los valores desmaterializados (bilateralmente o por contrato con una empresa de depósito), cuya existencia empezó a ser posible únicamente en virtud de las misma Ley No 18.876, antes de ella no podían ser objeto de prenda porque no existían; y desde su fecha tampoco en el caso de no estar depositados, porque, en la economía del artículo 11, creador de la nueva figura, resultaba imposible la desmaterialización sin depósito; en consecuencia, por simple aplicación de la regla del inciso $1^{\circ}$ del artículo 14, de ser pignorable un valor depositado solo cuando era pignorable sin estar depositado, tampoco se los pudo pignorar en cuanto depositados ${ }^{18}$. Dogmáticamente y desde el punto de vista del orden público económico, empero, no hubo ninguna razón para impedir la pignoración de valores desmaterializados en los términos del artículo 11; pero la misma ley bloqueó la operación merced a la rígida regla que impuso el inciso $1^{\circ}$ de su artículo 14 .

Sin embargo, los generales artículos 1 y 5 de la "Ley de prenda sin desplazamiento", que autorizan la pignoración de muebles incorporales, de suyo y por sí mismos hacen procedente la de los valores desmaterializados (uni- o bilateralmente), precisamente porque son muebles incorporales ${ }^{19}$. A mayor abundamiento, en fin, y no sin cierta redundancia, el artículo 8 de la misma ley expresó: "Los valores emitidos sin impresión física del título que los evidencie, podrán ser prendados bajo las disposiciones de la presente ley, [...]"20. Ello, por cierto, se aplica a los valores desmaterializados tanto uni- como bilateralmente.

Sigue en pie, sin embargo, que cuando los valores fueron desmaterializados bilateralmente, como entonces no pueden cumplir con la regla del inciso $1^{\circ}$ del artículo 14 de la Ley No 18.876, su pignoración no se funda, además, en esa ley. En cuanto a los desmaterializados unilateralmente, desde que la nueva "Ley de prenda sin desplazamiento” admite su empeño sin más, pueden serlo sin estar depositados y, por consiguiente, su pignoración cuando lo están se funda, además, en el mencionado artículo 14.

\footnotetext{
${ }^{17}$ Los valores con emisión física de título caen bajo el concepto de cosa corporal mueble, sobre las cuales el artículo 4 inciso $2^{\circ}$ de la Ley No 18.112 admite la prenda que estatuye.

18 No cabía pensar en la pignoración de valores desmaterializados con recurso a la Ley No 18.112, de 1982, porque esta se aplica solo a los muebles corporales (artículo 4 inciso $2^{\circ}$ ), y aquellos son incorporales. 19 No por estar desmaterializados, sino por consistir en derechos personales de crédito. Su carácter mueble deriva de recaer sobre dinero.

${ }^{20}$ En otras legislaciones la prenda de valores en cuenta aun es considerada bajo la óptica del desplazamiento, aunque sea ficticio. Así el artículo 10 de la Ley No 24: del Mercado de Valores, de 28 de julio de 1988, de España, expresa: "La constitución de derechos reales limitados u otra clase de gravámenes sobre valores representados por medio de anotaciones en cuenta deberá inscribirse en la cuenta correspondiente. La inscripción de la prenda equivale al desplazamiento posesorio del título". Sobre esta prenda, véase: DíAZ MORENO, Alberto (1991); CAMACHO Clavijo, Sandra (2003); CORTÉS GARCÍA, E. (2002), pp. 272-298.
} 


\section{PIGNORACIÓN DE VALORES Y TENENCIA}

La naturaleza del objeto de la pignoración sin desplazamiento de que tratamos imprime una mudanza en el régimen normal de sus efectos. En general, tal forma de prenda permite conservar la tenencia de la cosa pignorada al constituyente del gravamen y aquella no pasa al pignoratario (artículos 1 y 18), como sí acaece en la prenda real civil y comercial. Ahora bien, la pignoración sin desplazamiento de títulos de valores depositados en una empresa de custodia no deja como tenedor de los títulos al constituyente del gravamen, precisamente porque es la empresa la tenedora, y esta no pierde la tenencia con la pignoración. De más está decir que la tenencia tampoco pasa al pignoratario. La situación es muy semejante a la prenda de mercaderías depositadas en almacenes generales de comercio, regida por la Ley No 18.690 , de $1988^{21}$, porque tampoco la mercadería pignorada a través del endoso del vale de prenda que la representa (artículo 6 inciso $2^{\circ}$ de la Ley $N^{o} 18.690$ ), queda en la tenencia del pignorante (ni del pignoratario), sino de un tercero cualificado, como es el almacenista depositario (que debe estar inscrito como tal), y solo de él ${ }^{22}$.

Cuando la pignoración atañe a valores desmaterializados, no podemos hablar propiamente de su tenencia, porque esta es una noción de claros rasgos materiales o físicos, incompatible, por ende, con la idea misma de desmaterialización. La anotación en cuenta del valor solo por lejana analogía podría ser mirada como un equivalente funcional de la tenencia que se da en el depósito de objetos corporales. En tales circunstancias no hay cuestión de tenencia propiamente en la pignoración de valores desmaterializados ni, por ende, de su desplazamiento o no desplazamiento. Todo lo que se puede decir es que los valores pignorados siguen anotados en la cuenta del pignorante (y por la misma analogía podemos decir que siguen bajo su tenencia y no hay desplazamiento). Por consiguiente, la autorización de pignorar valores desmaterializados en los términos de la Ley No 20.190 no es para evitar su desplazamiento y conservarlo en el pignorante, sino únicamente para hacer viable la pignoración de tales valores, que de otra manera no cabría, y someterla a algún régimen. Por ello el artículo 8 de la ley dice: "Los valores emitidos sin impresión física del título que los evidencie, podrán ser prendados bajo las disposiciones de la presente ley [...]; y no: "Los valores emitidos sin impresión física del título que los evidencie, podrán ser prendados", en el entendido que el último verbo hubiera significado: "prendados sin desplazamiento"23.

${ }^{21}$ DO. de 2 de febrero de 1988.

22 Por lo cual, mirada esta prenda desde el punto de vista del pignorante, ella es con desplazamiento. Cierto es que este se había producido desde antes, con el depósito, que lo implica por sí mismo; pero una vez pignorada la mercadería en guarda, el desplazamiento adquiere un carácter fuerte, porque el depositante ya no puede retirar la mercadería del almacén, como podría hacerlo cuando no las hubiera pignorado; si lo hace, comete incluso delito (artículo 36 No 1 de la ley).

23 Con esto la ley evita en Chile una discusión sobre la aplicabilidad del requisito del desposeimiento, propio de la prenda civil o comercial, a la prenda de valores desmaterializados, que aun subsiste en otras legislaciones, como la italiana; véase, al respecto: CALLEGARI, Mia (2004), pp. 71 ss. Véase la nota 20. 


\section{EL PROCEDIMIENTO DE PIGNORACIÓN DE LOS VALORES DESMATERIALIZADOS}

\section{SUJECIÓN GENERAL DE LA PIGNORACIÓN DE VALORES DESMATERIALIZADOS A LAS REGLAS DE LA LEY No 20.190}

La pignoración sin desplazamiento de valores desmaterializados queda sometida a todas las reglas generales que establece el artículo 14 de la Ley No 20.190, las cuales, en esquema, consisten: $i$ ) en la celebración del contrato prendario sometido principalmente a los artículos 2 y 3 del citado artículo $14^{24}$; y ii) en la inscripción de aquel contrato en el Registro de Prendas sin Desplazamiento, para que pueda emerger el derecho real de prenda ${ }^{25}$, como ordena el artículo 24 también del artículo 14 y reitera el inciso $3^{\circ}$ de su artículo 8: "Lo dispuesto en los incisos anteriores es sin perjuicio de la obligación establecida en el Título IV de la presente ley". El "título 40" de la ley, como su rubrica: De la inscripción del contrato de prenda, de su modificación y su alzamiento lo anuncia, trata principalmente, en efecto, de la inscripción del contrato prendario en el Registro de Prendas sin Desplazamiento ${ }^{26}$.

Pero, además, el procedimiento de pignoración de valores desmaterializados tiene caracteres y exigencias peculiares, que advertimos en los artículos 13 y 14 de la Ley No 18.876 y 8 de la nueva "Ley de prenda sin desplazamiento".

\section{EL CERTIFICADO DE VALORES EN DEPÓSITO}

a) El artículo 13 de la Ley No 18.876 regula cierto certificado que las empresas de depósito deben emitir: "La empresa a requerimiento escrito del depositante, deberá certificar la cantidad, tipo, clase, especie, calidad y emisor de los valores que este mantiene en depósito. Estos certificados serán nominativos, intransferibles y no negociables y deberán ser suscritos por el gerente de la empresa o por la persona que este designe especialmente al efecto. [Inciso 20] Los certificados, que indicarán la fecha y hora de su otorgamiento, deberán individualizar los valores de que se trate". El documento de que trata esta disposición atañe tanto a los valores titulados como a los desmaterializados que se encuentran en depósito; y cumple función general, es decir, no limitada, por ejemplo, a la eventual pignoración de valores ni a ninguna otra específica. En todo caso, cabe insistir en que el documento no es un título de valor él mismo, debido a lo cual es nominativo e intrans-

\footnotetext{
24 Sobre él, véase: GUZMÁN BRITO, Alejandro (2009), pp. 161-236.

25 Sobre el cual, véase: GUZMÁn BRITO, Alejandro (2010), pp. 101-159.

${ }^{26}$ La reiteración de este inciso fue innecesaria. Pese a que los dos incisos anteriores del artículo 8 tratan de ciertas especiales anotaciones de la prenda, no hay modo de entender que ellas excluyen la general exigencia de inscripción del contrato en el mencionado registro. El legislador escribió el inciso 30, empero, bajo el temor de que pudiera entenderse excluida tal exigencia. Por lo demás, el artículo 19 del Reglamento del Registro de Prendas sin Desplazamiento expresamente reconoce la necesidad de la inscripción del contrato: "[...] las acciones, bonos $u$ otros valores que sean emitidos sin impresión del título que los evidencie, podrán ser prendados bajo las disposiciones de la ley, en cuyo caso, una vez inscrito <el contrato> en el Registro de Prendas sin Desplazamiento, la parte [...]". Es evidente que, en esta frase, el complemento directo de "inscrito" es "el contrato" (de prenda), que hemos suplido en la transcripción.
} 
ferible y no negociable ${ }^{27}$. Como lo señala su denominación, se trata de un mero certificado que da cuenta fehaciente de un hecho: el de que tales y cuales valores -sean titulados, sean desmaterializados- se encuentran depositados en cierta empresa de custodia de valores.

b) Sin embargo, pese a la función general del certificado, el inciso $2^{\circ}$ del mismo artículo 14 de la Ley No 18.876 lo aprovecha para efectos de la pignoración de valores (y de la imposición de otros gravámenes); pues expresa: "Para este efecto [sc. el de constituir prenda y otros derechos reales], a solicitud del depositante la empresa de depósito le entregará un certificado de los que se refiere el artículo anterior, que acredite la cantidad de valores que tiene depositados. A solicitud del depositante el certificado puede restringirse a solo parte de los valores que tenga entregados en depósito". Esta norma, pese a hablar de "valores" sin distinguir, en su sentido original atañía solo a los que constaran en títulos depositados en una empresa de custodia; y no, por consiguiente, a los valores desmaterializados, que no podían ser pignorados ni gravados de otra manera por impedirlo la regla del inciso $1^{\circ}$ del mismo artículo 14, así que un certificado "para el efecto de pignorarlos" ("Para este efecto [...]") era inútil a su respecto.

Cuando se emplea el certificado a efectos de la pignoración de los valores (o de imposición de otros gravámenes), la ley añade una especial naturaleza relativa al certificado en el inciso 40 del artículo 14: "Para los efectos de las formalidades necesarias para la constitución de la prenda u otro derecho real, el certificado reemplazará al título representativo del valor de que se trate". Aunque el certificado, pues, no es en sí mismo un título negociable y transferible, reemplaza al título del valor sobre que versa. El sentido de la norma es este: si es que se hace necesaria la exhibición del título del valor, entonces basta la exhibición del certificado, pues este reemplaza legalmente a aquel. Ahora bien, esta naturaleza representativa del certificado es solo para "los efectos de las formalidades necesarias para la constitución de la prenda u otro derecho real"; vale decir, carece de valor absoluto $^{28}$. De este modo, por ejemplo, si se desea pignorar civilmente bonos cuyos títulos han sido depositados en una empresa de custodia de valores, la entrega de los títulos exigida por la ley para la perfección de esa prenda se cumple con la entrega del certificado.

c) La posterior Ley No 19.623, de $1999^{29}$, en su artículo 2o No 4, añadió el siguiente artículo 14 bis a la Ley No 18.876: "Los certificados que la empresa emita en virtud de lo dispuesto en los artículos 13 y 14, tendrán mérito ejecutivo en contra de los emisores, y demás personas obligadas a su pago. Para el efecto de demandar su cobro, dichos

27 Lo cual no impide que se le atribuya mérito ejecutivo. Véase el artículo 14 bis: "Los certificados que la empresa emita en virtud de lo dispuesto en los artículos 13 y 14, tendrán mérito ejecutivo en contra de los emisores, y demás personas obligadas a su pago. Para el efecto de demandar su cobro, dichos certificados reemplazarán a los títulos de los valores depositados que representan, aun en los casos en que los títulos hayan sido refundidos en virtud de lo dispuesto en el artículo 10 o consten del registro de anotaciones en cuenta de que trata el artículo 11. [Inciso $2^{\circ}$ ] Los certificados antes referidos podrán ser solicitados y emitidos a nombre de quienes, sin ser depositantes, hayan efectuado el pago por cuenta del emisor".

${ }^{28}$ Aunque en la práctica nada impide que se conserve su valor representativo al certificado incluso para otros efectos.

${ }^{29}$ DO. de 26 de agosto de 1999. 
certificados reemplazarán a los titulos de los valores depositados que representan, aun en los casos en que los titulos hayan sido refundidos en virtud de lo dispuesto en el artículo 10 o consten del registro de anotaciones en cuenta de que trata el artículo 11 ". Nos interesa la última frase, porque atañe a los valores anotados en cuenta, vale decir, desmaterializados. Ella aplica la figura del certificado de valores, en cuanto emitido en virtud de lo dispuesto también por el artículo 14 y, por ende, “a efectos de la pignoración” (e imposición de otros gravámenes), precisamente a los valores desmaterializados; de modo de suponer que el certificado previsto en ese artículo, a los dichos efectos, también puede tener por objeto tales valores ${ }^{30}$. De acuerdo con esta norma, el inciso $2^{\circ}$ del artículo 14 empezó a ser aplicable también a los valores desmaterializados.

d) Pero el punto, en realidad, carece de importancia legal, aunque la tenga práctica. Ocurre que, en materia de prenda sin desplazamiento -única procedente cuando de valores desmaterializados se trata- no está prescrita en general la formalidad de presencia, exhibición, inserción ni incorporación del título de un valor para poder ser este pignorado; así que tampoco es necesario que un certificado deba reemplazar en esa inexistente función al título. Lo cual vale también cuando lo que se pignora es un valor desmaterializado, que, sin tener título, puede ser certificado según el artículo 14.

El certificado, empero, cumple una innegable e insustituible función práctica para individualizar en el contrato prendario los valores que se van a pignorar, porque el artículo 3 de la nueva ley, en su No 3 exige que el contrato de prende también deba contener: "La individualización o la caracterización de las cosas empeñadas". Si las cosas por pignorar son valores desmaterializados, no hay instrumento más eficiente que el certificado para conocer lo que se pignora y en función de dejar constancia de ello en el contrato; así que incluso es aconsejable su inserción en la escritura pública o privada del contrato y hasta su protocolización. Pero, como ha quedado dicho, la nueva ley no exige semejante certificado entre sus formalidades.

\section{LA NOTIFICACIÓN NOTARIAL DE LA PRENDA}

a) El inciso $5^{\circ}$ del artículo 14 de la Ley No 18.876 prescribe: "Cualquiera que sea la clase de prenda o de derecho real, no será oponible a la empresa de depósito ni a terceros, mientras no haya sido notificada a esa empresa por un notario, sin perjuicio de las demás formalidades que procedan de acuerdo a la ley". Esta norma, pues, exige una "notificación" de la prenda a la empresa de depósito por un notario. La ausencia del trámite hace que la prenda constituida no sea oponible a la empresa misma ni a terceros. La dicción inicial: "Cualquiera que sea la clase de prenda" permite concluir que hoy el trámite en examen es una carga exigible también si la prenda es aquella sin desplazamiento de la Ley No 20.190 .

\footnotetext{
${ }^{30}$ La suposición era errónea: en 1999, cuando fue emitida la Ley No 19.623, los valores desmaterializados, que para ser tales necesariamente debían estar depositados, aún no admitían ser objetos de prenda, porque no había caso en que pudieran serlo aun sin estar en depósito, como exige el inciso $1^{\circ}$ del artículo 14 . Por cierto, como el fin de la ley no fue estatuir sobre la pignoración de valores, sino sobre el mérito ejecutivo del certificado, y puesto que este también es mencionado en el artículo 14, la nueva ley quiso ser lo más general posible.
} 
En cuanto a qué debe notificarse, la norma se limita a pedir que se notifique la prenda ("prenda [...] no haya sido notificada"). En este contexto, el vocablo "prenda", que es multívoco, significa, empero, "contrato de prenda". Idealmente, se cumple bien con este trámite si la notificación a la empresa consiste en entregarle una cédula que exprese el hecho de haberse celebrado un contrato de prenda, que se individualiza someramente y se añade una copia autorizada del mismo contrato.

No creemos que el artículo 8 de la nueva ley haya alterado el mecanismo de la notificación de que hemos tratado. El artículo 8, en efecto, autoriza al acreedor prendario para solicitar la anotación de la prenda en el registro de anotaciones en cuenta de la empresa de depósito directamente a esta; y eso es totalmente compatible con que se exija notificar la pignoración a la empresa mediante un notario. Por lo demás, este último trámite es requisito de oponibilidad de la pignoración a la empresa y a terceros, mientras que la anotación no tiene asignada una sanción, como veremos ${ }^{31}$; no se podría, pues, pretender suplir la notificación por la anotación.

b) La notificación notarial establecida en el inciso $5^{\circ}$ se erige en regla general, frente a una especial contenida en el inciso $6^{\circ}$ del mismo artículo 14 , que expresa: "Sin perjuicio de lo dispuesto en el inciso anterior, en el caso de prendas u otros derechos reales sobre valores en depósito, que se constituyan por un depositante de la empresa o su mandante, a favor de otro depositante o mandante, se entenderá notificada la empresa tanto de su constitución como de su alzamiento o cancelación, con las comunicaciones electrónicas simultáneas entre las partes y aquélla". La circunstancia de hecho exigible para que tenga efecto el dispositivo de esta norma es, pues, que la prenda sin desplazamiento sobre valores desmaterializados en depósito -que es la prenda que interesa aquí- sea celebrada entre dos depositantes de la misma empresa, vale decir, entre un depositante que la constituye como pignorante y otro en cuyo favor se constituye como pignoratario. Cuando tal acaezca, no es necesario que la prenda sea notificada a la empresa por un notario, y ese trámite va reemplazado por sendas comunicaciones electrónicas simultáneas entre el pignorante y el pignoratario (designados como "las partes" en la norma), de un lado, y la empresa (designada como "aquélla"), de otro. La ley parece suponer, pues, que, bien en una misma comunicación enviada por ambas partes a la empresa, bien en comunicaciones separadas de cada parte, pero remitidas al mismo tiempo a la empresa, le sea avisada a esta el hecho de la pignoración. Supuesta una u otra manera de comunicación, la ley dispone que la empresa "se entienda notificada" de aquel hecho. Esta manera de construir la información bajo la forma de una suerte de presunción (simplemente legal) debe mirarse así: probado el hecho de haber sido enviada la comunicación electrónica conjunta o las separadas se entiende notificada la empresa y esta solo puede alegar y probar en contrario el hecho de no haber recibido la comunicación. Si se prueba que la recibió, no puede alegar no haber sido notificada.

En este evento, la ley ordena informar electrónicamente la "constitución" de la prenda a la empresa; y por tal nuevamente debemos entender al contrato de prenda, someramente descrito y adjuntada su copia autorizada en formato electrónico ("pdf" u

31 Véase, más abajo, el número 4 letra b) de este mismo capítulo. 
otro). La norma añade que también se puede informar de esta manera el alzamiento o cancelación de las prenda. Lo cual no dice para el caso general de notificación por un notario, aunque por analogía cabe exigirlo.

\section{LA ANOTACIÓN DE LA PRENDA EN LA CUENTA DE VALORES EN DEPÓSITO DEL PIGNORANTE EN UNA EMPRESA DE CUSTODIA}

a) La prenda de que tratamos también debe ser anotada en la cuenta que el pignorante tenga asignada en la empresa de depósito de valores, en cuanto depositante de estos en ella. Esta vez la exigencia proviene del inciso $1^{\circ}$ del artículo 8 de la nueva ley, según el cual la prenda de valores emitidos sin impresión física del título que los evidencie: "deberá anotarse en el registro de anotaciones en cuenta que se lleve para estos efectos". La expresión final "para estos efectos" obliga a pensar que el registro de anotaciones en cuenta de que habla la norma debe ser uno especial para los valores desmaterializados pignorados, diferente, en consecuencia, del que se lleva para los valores desmaterializados libres de tal gravamen. Es plenamente concordante con este entendimiento lo que dispone el artículo 4 de la Ley No 18.876: "La empresa de depósito llevará una cuenta individual para cada depositante, en la cual registrará, en item separados, cada clase de valores homogéneos que aquél mantenga en depósito. Para los efectos de esta ley se entienden como valores homogéneos los que sean idénticos en cuanto a tipo, especie, clase, serie y emisor. [Inciso $2^{\circ}$ ] Los valores que sean gravados con derechos reales o queden sujetos a embargo o medida precautoria, serán registrados en item separados en la cuenta del respectivo depositante, y no se les considerará homogéneos respecto de los demás de su mismo tipo, especie, clase, serie y emisor".

El inciso $1^{\mathrm{o}}$ de esta última norma atañe a la cuenta individual de valores en depósito, no gravados con derechos reales ni sujetos a embargo o medida precautoria, que se compone de diversos ítemes separados, en cada uno de los cuales se anota la serie de valores homogéneos de cada depositante.

$\mathrm{El}$ inciso $2^{\circ}$ concierne a un ítem perteneciente a la cuenta de valores en depósito, pero separado de los demás, pues se reserva para los valores gravados con derechos reales o sujetos a embargo o medida precautoria. Aunque por el tipo, la especie, clase y serie y el emisor sean intrínsecamente homogéneos con otros coincidentes en tales rubros, no se los mirará como tales; y por ello se los registra aparte. Debemos entender que, en realidad, debe distinguirse diversos ítems para cada serie de valores pignorados homogéneos según su tipo, especie, clase, serie y emisor.

Así que, en síntesis, la pignoración de valores desmaterializados requiere que la sociedad de custodia anote los respectivos valores como pignorados en un ítem especial, lo cual implica descargarlos del ítem pertinente de la cuenta individual de valores en depósito, no gravados con derechos reales ni sujetos a embargo o medida precautoria, a que se refiere el inciso $1^{\circ}$, porque, de lo contrario, estarían contradictoriamente anotados dos veces; como no pignorados y como pignorados. Con la dicha anotación en un ítem de valores (homogéneos) pignorados se cumple la exigencia del inciso $1^{\circ}$ del artículo 8 , en orden a que la prenda haya de "anotarse en el registro de anotaciones en cuenta que se lleve para estos efectos". Bajo la palabra "prenda" también se alude dinámicamente al 
contrato prendario y al derecho real de prenda; y este último se anota cuando lo anotado es una referencia a la inscripción en el Registro de Prendas sin Desplazamiento, que es la que origina el derecho.

b) La ley no ha atribuido alguna consecuencia específica al evento de ser omitida la anotación de la prenda en el registro de anotaciones en cuenta del depositantepignorante que lleva la empresa de custodia de valores. No podría ser deducida la inoponibilidad como consecuencia, sobre la base de que la anotación en cuenta del valor como pignorado, según la exigencia del inciso $1^{\circ}$ del artículo 8 de la nueva ley, cae bajo la prescripción del general inciso $2^{\circ}$ del artículo 25 de la nueva ley, antes examinado y que retranscribimos: "[...] En caso de bienes sujetos a inscripción obligatoria en algún otro registro, la prenda será inoponible a terceros, mientras no se anote una referencia del contrato de prenda al margen de la inscripción correspondiente". Si se conectara esta norma con la obligación de anotar la pignoración de valores en la cuenta del depositante, la ausencia del trámite, en efecto, acarrearía la inoponibilidad de aquella a terceros. Pero no se debe establecer semejante conexión: la hipótesis del artículo 25 inciso $2^{\circ}$ de la nueva ley es que el bien pignorado esté sujeto " a inscripción” obligatoria en algún otro registro; pero el inciso $1^{\circ}$ del artículo 8 de la misma ley no sujeta la prenda de valores a cierta "inscripción" (como sí hace el artículo 5 de la Ley No 18.045: Sobre mercado de valores, según antes vimos); y obliga a meramente "anotarla" ("deberá anotarse") en el registro de anotaciones en cuenta. Ahora bien "registrar" es algo muy diferente que "anotar".

Se podría pensar bien en la inoponibilidad -derivada de una aplicación de la doctrina general de tal sanción y no, como acabamos de ver, en cuanto proveniente del empleo del inciso $2^{\circ}$ del artículo 25 de la nueva ley-, bien en su nulidad absoluta. La primera posibilidad debe desecharse, porque no ha sido establecida para el caso en las leyes. Es completamente dudoso que deba sancionarse con nulidad absoluta la ausencia del trámite en estudio, porque no consta que él haya sido prescrito como requisito o formalidad para el valor de la pignoración en consideración a su naturaleza, que es cuanto cabría exigir, por aplicación del artículo 1682 CC., para que tuviere lugar tal nulidad. De hecho, el artículo 8 de la nueva ley se limita a establecer un deber ("la prenda deberá anotarse"), que solo puede ser cumplido por la empresa de depósito, porque es la única que puede ejecutar la anotación; lo cual aparece corroborado por el artículo 4 de la Ley No 18.876, que expresamente menciona a la "empresa de depósito" como encargada de hacer las registraciones, o sea, las anotaciones de valores, tantos de aquellos libres de gravamen (inciso $1^{\circ}$ ), como de los gravados con derechos reales o sujetos a embargo o medida precautoria (inciso $\left.2^{\circ}\right)^{32}$. Por lo demás, parece excesivo pensar en la nulidad cuando se advierte que ni siquiera la produce omitir la inscripción del contrato prendario en el Registro de Prendas sin Desplazamiento.

Con todo, la omisión deja obligado al omitente que actuó con dolo o culpa a indemnizar los perjuicios causados a terceros por la falta de anotación en la cuenta. Por

32 Véase la transcripción de la norma más arriba, en el capítulo IV, 5 a). 
lo regular, tal responsabilidad debe recaer sobre la empresa ${ }^{33}$, por la razón dicha de ser la única habilitada para ejecutar la anotación; pero tal responsabilidad empieza a afectarla después que la pignoración le haya sido notificada por un notario o informada electrónicamente (artículo 14 incisos $5^{\circ}$ y $6^{\circ}$ de la Ley 18.876$)^{34}$, pues antes le es inoponible. Sin embargo, debe tenerse presente que los terceros pueden informarse de la pignoración de los valores que les interese merced a la consulta del Registro de Prendas sin Desplazamiento, aun cuando no se haya practicado la anotación en cuenta de los mismos valores como pignorados; y en tales circunstancias es más que probable la necesidad de aplicar el artículo 2330 CC. ${ }^{35}$.

\section{ENTREGA FORZOSA DE UNA COPIA DE LA INSCRIPCIÓN Y EVENTUAL DE} UNA COPIA DEL CONTRATO

El artículo 19 del Reglamento del Registro de Prenda sin Desplazamiento contiene una exigencia adicional y la posibilidad de una segunda: "[...] la parte interesada deberá requerir la anotación de la prenda en el registro de anotaciones en cuenta de los valores correspondientes entregando certificado de inscripción <del contrato prendario $>$ en el Registro de Prendas sin Desplazamiento y, si asi lo solicitara el encargado del registro de anotaciones en cuenta, copia del contrato de prenda donde se individualicen los valores prendados, lo que podrá ser provisto por medios escritos o electrónicos". La primera exigencia consiste en entregar al registro de anotaciones en cuenta (vale decir, a su encargado) una copia de la previa inscripción del contrato prendario en el Registro de Prendas sin Desplazamiento. La exigencia es racional y lógica porque la ley se había limitado a pedir que "la prenda" deba ser anotada en el registro de anotaciones en cuenta; y atendido que la palabra "prenda" tanto puede denotar el contrato prendario como el derecho real, el cual, a su vez, se constituye por la inscripción, el reglamento viene a aclarar que lo que debe anotarse en el registro de anotaciones en cuenta es el derecho real, que viene representado por la inscripción del contrato prendario en el Registro de Prendas sin Desplazamiento, certificado de la cual hay que exhibir y entregar en el acto de la anotación en cuenta. La segunda exigencia es solo posible: "[...] y, si asi lo solicitara el encargado del registro de anotaciones en cuenta, [entregando] copia del contrato de prenda donde se individualicen los valores prendados, lo que podrá ser provisto por medios escritos o electrónicos". El encargado del registro de anotaciones en cuenta está habilitado, pues, para

\footnotetext{
33 Véase el artículo 27 de la Ley No 18.876: "La empresa responderá de la culpa levísima en la ejecución de sus obligaciones, siendo en especial responsable por cualquier merma, extravio, pérdida, deterioro, destrucción o retardo en la restitución que experimenten los valores entregados en depósito y en los errores o retardos que se registren en los servicios de transferencia de valores y liquidación de operaciones, de los que se deriven perjuicios para los depositantes. Responderá también de la autenticidad e integridad de los valores que haya admitido en custodia, todo lo anterior, sin perjuicio de su derecho de repetir contra el depositante que haya incurrido o sea responsable por acción u omisión de las situaciones descritas en este artículo./ [Inciso 2o] En todos estos casos, la empresa deberá reponer a sus expensas la totalidad de las mermas sufridas por los depositantes tan pronto como estas se detecten o reclamen".

34 Véase, más arriba, el capítulo IV, 3.

35 Artículo 2330 CC. "La apreciación del daño está sujeta a reducción, si el que lo ha sufrido se expuso a él imprudentemente". Es parte de la prudencia negocial estudiar los títulos de un bien sobre el cual se negocia.
} 
solicitar la exhibición y entrega de una copia del contrato de prenda. Pero no se capta la razón de esta exigencia, la cual no puede ser, como aparenta, la de dejar en condiciones al encargado, de conocer la individualización de los valores dados en prenda: por mandato del artículo $3 \mathrm{~N}^{\circ} 3$ de la ley, en efecto, tal individualización debe constar necesariamente en el contrato ${ }^{36}$; pero acaece que la misma individualización ya hubo de quedar reflejada en la inscripción ${ }^{37}$, certificado de la cual, como acabamos de ver, siempre debe hacerse entrega al encargado; así que este de todos modos conoce la individualización de los valores pignorados ${ }^{38}$.

El artículo 19 del Reglamento, cuando añade: "lo que podrá ser provisto por medios escritos o electrónicos", deja abierta la alternativa de que la copia del contrato de prenda que pueda exigir el encargado del registro de anotaciones en cuenta pueda ser "escrita", o sea, en papel, o bien "electrónica"; y que su entrega misma pueda hacerse mediante el traspaso del escrito o una remisión electrónica de la copia de ese mismo carácter (por correo electrónico, por ejemplo).

\section{SuJETOS HABILITADOS PARA SOLICITAR LA ANOTACIÓN DE LA PRENDA}

a) Las leyes ofrecen algunas reglas sobre habilitación para pedir la anotación de la prenda en al cuenta del depositante. Ya ha quedado dicho que tal anotación es un deber de la empresa. Insistamos en que tal deber se desencadena desde que tiene lugar la notificación o la información de la prenda a la empresa, en los términos de los incisos $5^{\circ}$ y $6^{\circ}$ del artículo 14 de la Ley No 18.876. Pero, por cierto, nada de lo anterior impide que la empresa sea instada a anotar. Al respecto, el artículo 8 de la nueva ley expresa: "[Inciso $1^{\circ}$ ] Los valores emitidos sin impresión física del título que los evidencie, podrán ser prendados bajo las disposiciones de la presente ley, en cuyo caso la prenda deberá anotarse en el registro de anotaciones en cuenta que se lleve para estos efectos./ [Inciso 20] Tratándose de valores depositados en una empresa de depósito de valores constituida de acuerdo a la ley $N^{o}$ 18.876, el acreedor prendario podrá solicitar la anotación de la prenda directamente a dicha empresa".

La secuencia de ambos incisos da la sensación de tratar una situación distinta cada uno. La diferencia parece consistir en que el inciso $1^{\circ}$ no atañe a valores depositados en una empresa de depósito formada de acuerdo con la ley No 18.876, que sí es, en cambio, el tema del inciso $2^{\circ}$. Esta distinción termina mostrándose correcta, porque, como vimos al comenzar, si bien la regla general es la desmaterialización bilateralmente

\footnotetext{
36 De modo que la norma: "[...] copia del contrato de prenda donde se individualicen los valores prendados" crea la sensación de ser posible que no se los individualice, aunque bloquee tal posibilidad. Ahora bien, el contrato debe necesariamente contener la individualización y entonces no puede ser que se entregue copia del mismo en que no aparezca ella; si no la contiene, es nulo.

37 Cfr. el artículo $5 \mathrm{~N}^{\circ} 16$ del Reglamento: "En el caso de cosas que no se encuentren indicadas en los números anteriores, deberá individualizarse o singularizarse la o las cosas que se constituyan en prenda, de manera tal que puedan distinguirse de cualquier otra, atendida su calidad o especie".

38 Es criticable, además, que la exigencia se haya dejado al arbitrio del encargado del registro de anotaciones en cuenta, quien, por ende, podría formularla discriminatoriamente para unos y no para otros, y a posteriori, al serle requerida la anotación. Como ello fuere inconstitucional, cabe interpretar que estos encargados tienen la carga de preanunciar si la formularán para todos o si no la formularán; y no puede aceptarse que pidan el contacto a unos y no a otros y que no lo preanuncien en general.
} 
acordada entre un emisor de valores y una empresa de custodia constituida al amparo de la Ley No 18.876, hay casos de desmaterialización unilateralmente dispuesta, como el de las acciones de sociedades anónimas abiertas, previa autorización de la Superintendencia de Sociedades Anónimas, de acuerdo con lo señalado por el inciso $4^{\circ}$ del artículo 12 en la Ley No 18.046; y el de la emisión de bonos y otros valores representativos de deuda pública que haga circular el Estado, en los términos del artículo 47 bis del Decreto-ley No 1.263. Como en estos casos no necesariamente interviene una sociedad de custodia de valores, resulta entonces que el inciso $2^{\circ}$ del artículo 8 de la "Ley de prenda sin desplazamiento" no es aplicable a la pignoración de los valores desmaterializados unilateralmente. Pero la anotación de la prenda, en cambio, pedida por el inciso $1^{\circ}$, es, en cambio, siempre exigible, sea que los valores desmaterializados estén depositado en una empresa de custodia, sea que no, por haber sido unilateralmente desmaterializados, porque el inciso $1^{\circ}$ del artículo 8 no distingue.

b) Así, pues, cuando se trata de la pignoración de valores bilateralmente desmaterializados, que por necesidad se encuentran depositados en una empresa de custodia, o de valores unilateralmente materializados y que fueron voluntariamente depositados en una tal empresa, la imprescindible anotación de la prenda en la cuenta del depositante, que exige y pone a cargo de la misma empresa el inciso $1^{\circ}$ del artículo 8 , puede, con todo, serle solicitada directamente por el acreedor prendario. La razón de la norma radica en que este último es un tercero para la empresa, ante quien ella aparece como legalmente dueña de los valores ${ }^{39}$; y en que la cuenta pertenece al depositante quien es, en principio, el único que la puede gestionar e intervenir; así que la empresa no tiene por qué obsequiar las peticiones que le haga un tercero como el pignoratario con relación a un instrumento, como la cuenta, que le es del todo ajena. La ley, pues, necesitó habilitar expresamente al pignoratario o acreedor prendario para solicitar a la empresa la anotación de la prenda en la cuenta del pignorante.

c) En el caso de la pignoración de valores unilateralmente desmaterializados y que en la actualidad no se encuentran depositados en alguna empresa de custodia, también rige la exigencia del artículo 8 inciso $1^{\circ}$ de la nueva ley, en orden a deber ser anotada la prenda en el registro de anotaciones en cuenta que se lleve para esos efectos. Para el caso de la desmaterialización unilateral de bonos y otros valores representativos de deuda pública que emita el Estado, según la autorización dada por el artículo 47 bis del Decreto-ley No 1.263 Orgánico de la administración financiera del Estado ${ }^{40}$, su inciso $3^{\circ}$ prevé que el emisor, vale decir, el Estado: "deberá mantener un registro de anotaciones en cuenta a favor de los tenedores de los correspondientes valores representativos de la deuda pública". Es, pues, en ese registro de anotaciones en cuenta en donde deberá darse cumplimiento a lo que pide el artículo 8 inciso $1^{\circ}$ de la nueva ley, de anotarse la prenda, como un ítem especial que se lleve para esos efectos.

\footnotetext{
39 Artículo 5 inciso $1^{\circ}$ de la Ley No 18.876: "En las relaciones entre la empresa y el depositante, este es el propietario de los valores depositados a su nombre. Ante el emisor de los valores y terceros [...] la empresa es considerada dueña de los valores que mantiene en depósito [...]".

40 DO. 28 de noviembre de 1975 .
} 
No encontramos dicho algo semejante en tema de desmaterialización unilateral de acciones de sociedades anónimas abiertas, previa autorización de la Superintendencia de Valores y Seguros, a que se refiere el inciso $4^{\circ}$ del artículo 12 en la Ley No 18.046: Sobre sociedades anónimas ${ }^{41}$. Pero como el artículo 8 inciso $1^{\circ}$ de la nueva "Ley de prenda sin desplazamiento" es absoluto y no exime de la anotación que ahí se exige a estas acciones así desmaterializadas, una de tres: o la sociedad anónima abierta emisora anota la pignoración en la cuenta de acciones desmaterializadas que necesariamente ha de llevar; o deposita tales acciones en una empresa de custodia de valores y se las somete al régimen de inciso $2^{\circ}$; o no se pueden pignorar dichas acciones por ser imposible la anotación.

d) Se tendrá presente que el artículo 19 del Reglamento del Registro de Prendas sin Desplazamiento no añade algo interesante al disponer sobre esta materia; pues se limita a decir: "De acuerdo con el artículo $8^{\circ}$ de la Ley, las acciones, bonos $u$ otros valores que sean emitidos sin impresión física del título que los evidencie, podrán ser prendados bajo las disposiciones de la Ley, en cuyo caso, una vez inscrita en el Registro de Prendas sin Desplazamiento, la parte interesada deberá requerir la anotación de la prenda en el registro de anotaciones en cuenta de los valores correspondientes [...]". En efecto, la norma legitima para pedir la anotación a la "parte interesada", así en general y de manera puramente formal.

\section{INEXIGENCIA DE LA ANOTACIÓN DEL CONTRATO PRENDARIO EN EL Registro de Valores de la Superintendencia de VAlores Y SEGUROS}

Para su oponibilidad a terceros, la prenda sin desplazamiento de valores desmaterializados no exige la anotación del contrato prendario en el Registro de Valores que administra la Superintendencia de Valores y Seguros.

El general inciso $2^{\circ}$ del artículo 25 de la nueva ley expresa: "[...] En caso de bienes sujetos a inscripción obligatoria en algún otro registro, la prenda será inoponible a terceros, mientras no se anote una referencia del contrato de prenda al margen de la inscripción correspondiente". Pero esta disposición no cubre la inscripción prevista por el artículo 5 de la Ley No 18.045: Sobre mercado de valores, en donde se lee: "La Superintendencia llevará un Registro de Valores el cual estará a disposición del público. En el Registro de Valores se deberán inscribir: a) [...]; b) Los valores que sean objeto de oferta pública; c) Las acciones de las sociedades anónimas que tengan 500 o más accionistas o [...], y d) Las acciones emitidas por sociedades anónimas que voluntariamente asi lo soliciten o que por obligación legal deban registrarlas. [...]”. Lo que debe inscribirse en el Registro de Valores aludido no es cada valor o acción individuales, ni conjuntos de tales pertenecientes a determinada persona, sino la emisión o serie de los valores generados, sobre la base de cierta información concerniente a la situación jurídica, económica y financiera del emisor $^{42}$. Su fin, pues, no es mantener cierta historia de los valores concretos, sino informar al público inversionista sobre la solvencia del emisor de los valores en cuanto género. En

${ }^{41}$ DO. de 22 de octubre de 1981. El mentado inciso $4^{\circ}$ fue modificado por el artículo 2 No 7 letra b) de la Ley No 20.382, publicada en el DO. de 20 de octubre de 1989. 
tales circunstancias, la superintendencia no podría aceptar a inscripción un contrato de prenda sobre determinados valores. Por consiguiente, la pignoración sin desplazamiento de valores, para ser oponible a terceros, no exige la anotación de una referencia al correspondiente contrato de prenda al margen de la inscripción de la emisión a la cual pertenece el valor pignorado en el Registro de Valores de la Superintendencia.

\section{REQUISITO ADICIONAL DE LA PIGNORACIÓN DE VALORES TENIDOS POR OPERADORES DE TALES A NOMBRE PROPIO Y POR CUENTA DE TERCEROS \\ El artículo 179 inciso $1^{\circ}$ de la Ley No 18.045: De mercado de valores, incorporado} ahí por el artículo primero No 18 letra b) de la Ley No $19.301^{43}$, expresa: "Los agentes de valores, corredores de bolsa, bolsas de valores, bancos, o cualquier otra entidad legalmente autorizada, que mantenga valores por cuenta de terceros pero a nombre propio, deberá inscribir en un registro especial y anotar separadamente en su contabilidad estos valores con la individualización completa de la o las personas por cuenta de quien los mantiene. Este registro hará fe en contra de las personas señaladas, pudiendo los interesados reclamar en todo tiempo sus derechos, valiéndose de cualquier medio de prueba legal'. Como puede percibirse, el precepto impone a los operadores de valores que indica, el deber de inscribir en un registro especial suyo los valores de terceros que mantienen a nombre propio (amén de anotarlos en su contabilidad, en forma separada). Esta inscripción debe incluir la individualización completa de los terceros cuyos valores tiene en nombre propio el operador.

Ahora bien, el artículo 25 inciso 2o de la nueva "Ley de prenda sin desplazamiento", cuyo tenor reza: "En caso de bienes sujetos a inscripción obligatoria en algún otro registro, la prenda será inoponible a terceros, mientras no se anote una referencia del contrato de prenda al margen de la inscripción correspondiente" cubre la inscripción exigidas en la norma primeramente transcrita. Por consiguiente, si lo pignorado consiste en valores -desmaterializados o no- que se encuentran en poder de operadores como agentes de valores, corredores de bolsa, bolsas de valores, bancos, o cualquier otra entidad legalmente autorizada ${ }^{44}$, su pignoración es inoponible a terceros mientras no se anote una referencia del contrato prendario en el registro de valores de terceros que el operador que los tiene por cuenta propia debe llevar, todo ello merced a lo dispuesto por el artículo 25 de la nueva "Ley de prenda sin desplazamiento".

\footnotetext{
42 Cfr. el artículo 8 de la Ley No 18.045: "La Superintendencia deberá efectuar la inscripción en el Registro de Valores, una vez que el emisor le haya proporcionado la información que esta requiera sobre su situación jurídica, económica y financiera [...]". La Superintendencia tiene regulada la inscripción en el Registro de Valores mediante normas de carácter general; véase la No 118 de 15 de mayo de 2001, modificada por la No 183 de 5 de julio de 2005. El contenido de las exigencias y procedimiento necesarios para inscribir es suficientemente informativo del verdadero carácter del acto, que indicamos en el texto.

43 DO. de 19 de marzo de 1994

${ }^{4}$ Se tendrá presente que los valores en referencia necesariamente deben ser depositados por el operador en una empresa de custodia, tal cual lo establece el inciso $2^{\circ}$ del mismo artículo 179: "Las personas indicadas en el inciso anterior que mantengan en su custodia valores de terceros, deberán abrir una cuenta destinada al depósito de dichos valores en una empresa de depósito y custodia de valores regulada por la ley $N^{\circ} 18.876$. No obstante lo anterior, en el caso que los dueños de dichos valores asi lo requieran, el intermediario deberá abrir cuentas individuales a nombre de aquéllos".
} 


\section{REQUISITOS ESPECIALES Y ADICIONALES DE LA PRENDA SOBRE VALORES CONSISTENTES EN ACCIONES DESMATERIALIZADAS}

En tema de prenda de acciones hay dos requisitos especiales en su pignoración, que se añaden a la de los generales de todo valor.

a) Según el artículo 23 de la Ley No 18.046: Sobre sociedades anónimas ${ }^{45}$ : “La constitución de gravámenes y de derechos reales distintos al del dominio sobre las acciones de una sociedad, no le serán oponibles a esta, a menos que se le hubiere notificado por ministro de fe, el cual deberá inscribir el derecho o gravamen en el Registro de Accionistas". En su generalidad, la norma incluye la prenda, y no distingue especies de tal, así que también abraza a la prenda sin desplazamiento de acciones, bien tituladas, bien desmaterializadas (uni- o bilateralmente). Por consiguiente, para que esta última -que es la que nos interesa- sea oponible a la sociedad anónima emisora de las acciones menester es que un ministro de fe le haya notificado la prenda, vale decir, el contrato prendario.

b) El mismo artículo 23 de la Ley No 18.046, en su parte final, impone al ministro de fe que notifique la pignoración a la sociedad anónima emisora, el deber de inscribir el gravamen en el Registro de Accionistas de la sociedad. El punto también se encuentra contenido en el artículo 13 del Reglamento de sociedades anónimas, contenido en el Decreto supremo No 568, del Ministerio de Hacienda, de 198246; el cual expresa: "Las sociedades anónimas deberán llevar un Registro de Accionistas en el que se anotará, a lo menos, el nombre, domicilio y cédula de identidad de cada accionista, el número de acciones de que sea titular, la fecha en que estas se hayan inscrito a su nombre y tratándose de acciones suscritas y no pagadas, la forma y oportunidades de pago de ellas. Igualmente, en el Registro deberá inscribirse la constitución de gravámenes y de derechos reales distintos al de dominio".

Esta inscripción es más que la "anotación de una referencia"; por lo mismo, una vez ejecutada, sirve para dar por cumplido el requisito que deriva del artículo 25 inciso 2o de la nueva ley: "En caso de bienes sujetos a inscripción obligatoria en algún otro registro, la prenda será inoponible a terceros, mientras no se anote una referencia del contrato de prenda al margen de la inscripción correspondiente". De acuerdo con este precepto, en efecto, como las acciones deben inscribirse en el Registro de Accionistas, su pignoración exige anotar una referencia al contrato prendario en aquel. Pero, como según los artículos 23 de la Ley No 18.046 y 13 del Reglamento de sociedades anónimas, el gravamen hay que inscribirlo en ese mismo registro, he ahí lo dicho en orden a que esta inscripción cubre e incluye la mera anotación de una referencia; y no es necesario, pues, ejecutar la inscripción y la anotación, mas únicamente la primera.

\section{LEGITIMACIÓN PARA PIGNORAR VALORES BILATERALMENTE DESMATERIALIZADOS}

En materia de valores desmaterializados, no resulta derogada la regla general sobre legitimación para pignorar sin desplazamiento, que la radica en el dueño del objeto que

${ }^{45} D O$. de 22 de octubre de 1981.

46 DO. de 13 de noviembre de 1982 
se trata de empeñar ${ }^{47}$. La prenda a non domino, sin embargo, vale, pero es inoponible al verdadero dueño ${ }^{48}$. Con todo, la circunstancia de consistir el objeto en un valor desmaterializado y depositando modaliza la aplicación de esta regla.

Como hicimos ver al comenzar, los valores pueden ser depositados únicamente en una empresa de custodia y, por ende, desmaterializados contractualmente con ella, por las personas e instituciones enumeradas en el artículo 2 de la Ley No 18.876. Ahora bien, tales sujetos pueden depositar valores de su propiedad, caso en el cual actúan en nombre y por cuenta propios; o bien depositar valores ajenos -como acaece con frecuencia en el mercado de clientes y agentes profesionales-; en tal hipótesis, pueden actuar en nombre propio y por cuenta ajena; o bien en nombre y por cuenta ajenos. En los dos primeros casos, empero, delante de la empresa de custodia los depositantes aparecen como dueños, séanlo o no. Así lo expresa el artículo 5 de la Ley No 18.876: "En las relaciones entre la empresa y el depositante, este es el propietario de los valores depositados a su nombre". La razón es que el depósito de los valores se ejecuta mediante la transferencia de su dominio a la empresa ${ }^{49}$; lo cual supone que el depositante sea a su vez el dueño, bien materialmente, porque este opera con valores adquiridos para sí, bien solo formalmente, porque le fueron transferidos por un tercero - un cliente- con el fin de que los deposite ${ }^{50}$.

\section{DEPÓSITO DE VALORES EN NOMBRE Y POR CUENTA PROPIOS}

En el evento de un depósito de valores en nombre y por cuenta propios, lo que supone una identificación del depositante como dueño en su cuenta, entonces tiene lugar lo dispuesto por el inciso $2^{\circ}$ del artículo 5 de la Ley No 18.876: "Los valores que se encuentren depositados en la empresa, solo podrán ser objeto de embargos, medidas prejudiciales o precautorias $u$ otras limitaciones al dominio por obligaciones personales del depositante, cuando fueren de su propiedad y asi lo identificare la cuenta respectiva [...]". La expresión "otras limitaciones al dominio" cubre, por cierto a la prenda sin desplazamiento (y con él, lo mismo que a otros gravámenes, como el usufructo, que aquí no interesan). La legitimación para pignorar los valores depositados corresponde sin más, pues, al depositante en quien concurre la calidad material de dueño. Es a tal evento al que se refiere propia, principal y directamente el artículo 14 de la Ley No 18.876: "El depositante puede constituir prendas y derechos reales sobre los valores que tenga depositados, en los mismos casos en que podría hacerlo si no estuvieren en depósito". También es aplicable, como adelantamos, el segmento inicial del artículo 5 inciso $1^{\circ}$ de la Ley 18.876: "En las

\footnotetext{
${ }^{47}$ Sobre la materia, véase: GUZMÁN BRITO, Alejandro (2008), pp. 401-422.

48 Artículo 13 de la nueva ley de prenda: "Solo el dueño podrá alegar la inexistencia del derecho real de prenda invocando su derecho de dominio sobre la cosa pignorada, sin perjuicio de la validez del contrato".

49 Artículo 3 de la Ley No 18.876: "El contrato de depósito se perfecciona mediante la entrega de los valores a la empresa, la que los registrará en la cuenta que corresponda, de las que mantenga el depositante respectivo. La entrega se hará mediante las formalidades propias de la transferencia de dominio, según sea la naturaleza del titulo de que se trate".

50 Se trata de una fiducia a la que Gayo, Instit. 2,60, denomina cum amico, o transferencia en función de mandato en este caso (porque también puede ser en función de comodato o de depósito).
} 
relaciones entre la empresa y el depositante, este es el propietario de los valores depositados a su nombre", porque no distingue si el depósito es por cuenta propia o por cuenta ajena y solo atiende a que sea en nombre propio.

Se observará que el inciso $2^{\circ}$ del artículo 5 primeramente transcrito restringe la legitimación para pignorar del depositante al caso de tratarse de garantizar obligaciones personales suyas. Esto significa que no podría constituir prenda por obligaciones de terceros, como sí es posibilidad normal por Derecho común (artículo 2388 CC.). Tal excepción no se justifica, atendido que es el dueño mismo el que eventualmente decide pignorar por obligaciones ajenas; pero se explica, porque la limitación se encuentra totalmente justificada en el caso de embargos y medidas prejudiciales o precautorias, que es el objeto directo y expreso de la dicción legal. El legislador quiso prever otros casos semejantes y recurrió a la expresión "otras limitaciones al dominio", sin advertir que con ella incluía la prenda, respecto de la cual, como quedó dicho, ya no se justifica la limitación y, por el contrario, se contradice el Derecho común.

\section{DEPÓSITO DE VALORES EN NOMBRE PROPIO Y POR CUENTA AJENA}

a) Puede acaecer que el depositante actúe en nombre propio y por cuenta ajena: el caso implica a un agente que administra valores de sus clientes. El artículo 179 de la ley No 18.045: De mercado de valores, da la siguiente norma dirigida a los agentes de valores, corredores de bolsa, bolsas de valores, bancos, o cualquier otra entidad legalmente autorizada "que mantengan en su custodia valores de terceros, deberán abrir una cuenta destinada al depósito de dichos valores en una empresa de depósito y custodia de valores regulada por la ley $N^{o}$ 18.876. No obstante lo anterior, en el caso que los dueños de dichos valores asi lo requieran, el intermediario deberá abrir cuentas individuales a nombre de aquéllos". De esta manera, las personas indicadas no solo pueden sino que deben, por mandato de la norma transcrita, depositar en una sociedad de custodia los valores de terceros que ellas administren. El depósito puede revestir dos modalidades: la primera es que sea a nombre propio del agente sin identificar al dueño de los valores, y es el caso que tratamos; la segunda es que sea a nombre del dueño de los valores, en cuenta individual para cada uno; la cual solo es necesaria si el dueño lo requiere, como señala la última parte del artículo 179 antes transcrito.

b) Supuesto el depósito de valores a nombre propio y por cuenta ajena de dueños no identificados antes la empresa, se hace aplicable el artículo 179 inciso $3^{\circ}$ de la ley No 18.045: De mercado de valores, del cual inciso interesa ahora solo su segmento final: "[...] podrán decretarse tales medidas, de conformidad a las reglas generales, cuando se trate de obligaciones personales de los terceros que le hayan entregado valores en depósito, respecto de los valores de propiedad del tercero respectivo". La expresión "tales medidas" hace referencia a "embargos, medidas prejudiciales o precautorias u otras limitaciones al dominio" que son expresamente mencionados en el segmento inicial de este inciso $3^{\circ}$. Como es lógico, los valores de terceros que el agente tenga en su poder o depositados (lo cual, como vimos, es una obligación suya) pueden ser embargados, objetos de medidas precautorias y de "otras limitaciones al dominio", entre las cuales queda incluida la prenda, cuando se trata de por obligaciones personales del tercero que sea dueño de tales valores 
que y los haya entregado al agente, quien los depositó. Nuevamente la prenda aparece limitada a obligaciones del dueño de los valores, no de terceros; pero esta vez la limitación se justifica bien en resguardo de los intereses del dueño.

c) Solo que todas estas operaciones ofrecen una dificultad: los valores de que se trata fueron depositados por un agente a nombre propio y por cuenta ajena, vale decir, por quien no es su dueño y sin identificación del tercero que sí lo es. ¿Cómo, pues, conectar la operación por obligaciones del dueño de los valores con este mismo? El segmento final que integra el inciso $2^{\circ}$ del artículo 5 de la Ley No 18.876 ofrece el mecanismo: "Tratándose de valores depositados por el depositante a nombre propio, pero por cuenta de terceros no identificados frente a la empresa, tales embargos o medidas solo podrán hacerse efectivas en el registro que dicho depositante lleve de conformidad al artículo 179 de la ley $N^{o}$ 18.045, de Mercado de Valores". La expresión "embargo o medidas" es una referencia al segmento inicial del inciso $2^{\circ}$ : "Los valores que se encuentren depositados en la empresa, solo podrán ser objeto de embargos, medidas prejudiciales o precautorias $u$ otras limitaciones al dominio [...]". Pero esta vez falta el complemento " $u$ otras limitaciones al dominio" en el segmento final del inciso $2^{\circ}$; y, con todo, lo entendemos tácitamente aludido para dar continuidad y unidad sistemática a la disposición entera. Consideramos, pues, que la norma también atañe a la prenda.

Ella remite al artículo 179 de la Ley No 18.045: De mercado de valores; que en su inciso $1^{\circ}$ expresa: "Los agentes de valores, corredores de bolsa, bolsas de valores, bancos, o cualquier otra entidad legalmente autorizada, que mantenga valores por cuenta de terceros pero a nombre propio, deberá inscribir en un registro especial y anotar separadamente en su contabilidad estos valores con la individualización completa de la o las personas por cuenta de quien los mantiene. Este registro hará fe en contra de las personas señaladas, pudiendo los interesados reclamar en todo tiempo sus derechos, valiéndose de cualquier medio de prueba legal'. La norma, pues, obliga a los operadores de valores que indica, a inscribir en un registro especial suyo y a anotar en su contabilidad, en forma separada e individualizada, los valores de terceros que administran en nombre propio. El inciso $2^{\circ}$ los obliga, como antes quedó dicho ${ }^{51}$, a depositarlos en una empresa de custodia ${ }^{52}$.

Así que los embargos y medidas precautorias, y las prendas sin desplazamiento añadimos nosotros, de los valores ajenos depositados por el agente a nombre propio solo pueden hacerse efectivas en el registro especial que el agente debe llevar por mandato del artículo 179 inciso $1^{\circ}$ de la Ley No 18.045. La razón es notoria: como el dueño de los valores no está identificado frente a la empresa (es el supuesto del artículo 5 inciso $2^{\circ}$ de la Ley No 18.876), los embargos y medidas precautorias contra tales valores por deudas del dueño (y las prendas) por tales deudas no tienen cómo hacerse afectivas sino con referencia al registro del agente, en que consta que tales valores pertenecen a determinado cliente suyo.

\footnotetext{
51 Véase la nota 44,

$52 \mathrm{El}$ inciso $3^{\circ}$, en su segmento inicial, deja a salvo los valores de terceros administrados por los agentes, en la siguiente manera: "En los juicios en que se persiga la responsabilidad de alguna de las personas indicadas en el inciso primero o la ejecución forzada de las obligaciones de estas con terceros o con depositantes, no se podrá, en caso alguno, embargar, ni decretar medidas prejudiciales o precautorias $u$ otras limitaciones al dominio respecto de los valores que les hubieren sido entregados en depósito".
} 
c) Para concentrarnos en la prenda, la que se constituya sobre valores depositados en una empresa de custodia, con o sin desmaterialización -aunque es el primer caso el que aquí nos interesa- a las exigencias generales que rigen la operación, a saber: i) la inscripción del contrato prendario en el Registro de Prendas sin Desplazamiento; ii) la notificación notarial o información electrónica de la prenda a la empresa de custodia; iii) la anotación de la prenda en la cuenta de valores en depósito que lleva la empresa de custodia; a todas las cuales se añaden estas otras dos cuando se trata de la prenda de acciones: i) la notificación de la prenda a la sociedad anónima emisora; y ii) la inscripción del gravamen en el Registro de Accionistas de la misma sociedad; a todo esto, si la prenda se constituye sobre valores depositados a nombre propio por cuenta ajena, se agrega, pues, que la prenda debe "hacerse efectiva" en el registro que el agente lleve merced al artículo 179 de la ley No 18.045, como ordena el inciso $2^{\circ}$ del artículo 5 de la Ley No 18.876. La acción que la ley describa como "hacer efectiva" no puede significar otra cosa que inscribir la operación de que se trate, vale decir, la prenda en nuestro caso.

d) Pero, ¿cómo se ejecuta la pignoración de valores depositados a nombre propio y por cuenta ajena?

Preliminarmente debe tenerse presente que la posibilidad se enfrenta, en principio, con el artículo 14 inciso $1^{\circ}$ de la Ley No 18.876: "El depositante puede constituir prendas y derechos reales sobre los valores que tenga depositados, en los mismos casos en que podría hacerlo si no estuvieren en depósito". Por consiguiente, el depositante en examen no podría pignorar el valor, porque, de no haber estado él depositado no hubiera podido hacerlo, precisamente por no ser su dueño. La pignoración ejecutada por el depositante sería a non domino. Pero si el depositante contaba con mandato (sin representación ${ }^{53}$ ) que lo autoriza a pignorar, la situación cambia de aspecto, porque entonces el dueño no puede desconocer la autorización de pignorar envuelta en el mandato, equivalente a una suerte de ratificación anticipada, que puede entrar en la órbita del artículo 13 inciso 20 de la nueva "Ley de prenda sin desplazamiento": "Si [...] el dueño ratificare el correspondiente contrato de prenda, se entenderá constituido el derecho real de prenda desde la fecha de su inscripción en el Registro de Prendas sin Desplazamiento".

Si el agente carece de mandato, puede recurrir al artículo 14 inciso $3^{\circ}$ de la Ley No 18.876: "Si el depositante declarare que el depósito lo efectuó a su propio nombre, pero por cuenta de un tercero, la empresa de depósito emitirá los certificados de que tratan el artículo 13 y el presente articulo a nombre de quien le indique el depositante, bajo exclusiva responsabilidad de este". En el momento del depósito a nombre propio, el agente no tuvo el deber de declarar que era por cuenta ajena; la empresa tampoco pudo exigirle aclararlo. Pero con posterioridad puede aquel manifestar la realidad de haber depositado por cuenta ajena y la empresa tiene el deber de aceptar su manifestación, solo que bajo la responsabilidad del depositante. Por consiguiente, la empresa debe emitir el certificado descrito en los artículos 13 y 14 de la Ley No 18.876 a

$53 \mathrm{Si}$ es con representación, el depositante actúa como apoderado o representante y es como si el dueño hubiera celebrado la pignoración (artículo 1448 CC.). El caso transita, pues, al de pignoración de valores depositados a nombre y por cuenta ajenos, que se verá seguidamente. 
nombre de quien indique el depositante y se supone que este indicará al dueño de los valores. Con el mérito de tal certificado, el dueño puede proceder a la pignoración de acuerdo con las reglas generales.

\section{DEPÓSITO DE VALORES A NOMBRE Y POR CUENTA AJENOS}

En fin, pudo acontecer que el agente haya depositado los valores a nombre y por cuenta ajenos: esto significa que identificó al dueño de tales valores ante la empresa de depósito. En tal caso, no se aplica el segmento inicial del artículo 5 inciso $1^{\circ}$ de la Ley 18.876: "En las relaciones entre la empresa y el depositante, este es el propietario de los valores depositados a su nombre", precisamente porque el depósito no fue en nombre de agente depositante; por el contrario, se dejó constancia de quién es su dueño y se lo identificó. Se recordará que un agente que recibe valores ajenos, tiene la obligación de depositarlos, según el dispositivo del artículo 179 de la ley No 18.045: De mercado de valores. Este depósito puede ser a nombre propio del agente (y por cuenta del dueño) -que fue el caso tratado precedentemente- o a nombre del dueño (y por cuenta del mismo) -que es el caso que ahora tratamos-, a elección del depositante; pero si el dueño lo requiere, el depósito debe hacer a nombre y por cuenta suyos en una cuenta individual ${ }^{54}$. Por cierto, en tal caso no se aplica el segmento inicial del artículo 5 inciso $1^{\circ}$ de la Ley 18.876: "En las relaciones entre la empresa y el depositante, este es el propietario de los valores depositados a su nombre". El depositante no puede pignorar los valores, porque lo impide el artículo 14 de la Ley No 18.876: "El depositante puede constituir prendas y derechos reales sobre los valores que tenga depositados, en los mismos casos en que podría hacerlo si no estuvieren en depósito", ya que, de no estar depositados no podría empeñarlos por no ser su dueño. El certificado de valores en depósito previsto por los artículos 13 y 14 de la Ley No 18.876 tiene que ser emitido por la empresa a nombre del dueño y no del depositante. Con su mérito, aquel puede celebrar la pignoración de los correspondientes valores. Por cierto, esta puede ser celebrada por el agente si tiene poder con representación del dueño.

En virtud del segmento segundo del artículo 5 inciso $2^{\circ}$ de la Ley No 18.876 , la pignoración, lo mismo que los embargos y medidas precautorias que afecten a los valores depositados a nombre y por cuenta de su dueño, quedan limitados a obligaciones personales suyas: "[...] Si los valores se encontraren depositados por encargo de terceros en cuentas que identifiquen el nombre del mandante, solo podrán ser objeto de las resoluciones antes indicadas por obligaciones contraidas por los señalados mandantes". La expresión "resoluciones antes indicadas" hace referencia a "embargos, medidas prejudiciales o precautorias $u$ otras limitaciones al dominio", mencionados en el segmento primero del inciso $5^{\circ} . \mathrm{Y}$ aunque no es apropiado hablar de "resoluciones" a propósito de "otras limitaciones al dominio", no se ve por qué deberían excluirse. La restricción a las obligaciones personales del dueño es sin más completamente lógica tratándose de embargos y medidas pre-

\footnotetext{
${ }^{54}$ Así lo expresa el segmento final del artículo 179 de la ley No 18.045: "No obstante lo anterior, en el caso que los dueños de dichos valores asi lo requieran, el intermediario deberá abrir cuentas individuales a nombre de aquellos".
} 
GuZmán Brito, Alejandro — "La prenda sin desplazamiento de valores desmaterializados o emitidos sin impresión..."

cautorias. Con respecto a la prenda que, por consiguiente, no puede constituirse para caucionar obligaciones de terceros, en contra del Derecho común, no se justifica en resguardo de los intereses del dueño porque, en principio, es este mismo quien celebra la pignoración y puede decidir qué obligaciones caucionar.

\section{UNA PRENDA ESPECIAL SOBRE VALORES DESMATERIALIZADOS}

1. La Ley $\mathrm{N}^{\circ}$ 20.345: Sobre sistema de compensación y liquidación de instrumentos financieros ${ }^{55}$ establece una prenda especial por responsabilidades y obligaciones derivadas de la liquidación y compensación de instrumentos financieros para los participantes en el sistema de tal liquidación y compensación. A la materia se refiere su artículo 26: "[Inciso $1^{\circ}$ ] Las sociedades administradoras deberán requerir garantías a los participantes para asegurar el cumplimiento de las obligaciones que estos asuman o que se deriven del ingreso de órdenes de compensación al sistema.l [Inciso $2^{\circ}$ ] Las normas de funcionamiento determinarán el tipo de garantías que se podrá utilizar, el cálculo del monto que deberán cubrir y la oportunidad en que serán exigibles a los participantes./ [Inciso $3^{\circ}$ ] [...]./ [Inciso $4^{\circ}$ ] Tratándose de instrumentos financieros depositados en una empresa de depósito y custodia de valores, la constitución, alzamiento o modificación de dichas garantías se efectuará de conformidad con el artículo 14 de la ley $N^{\circ}$ 18.876. Las prendas se entenderán irrevocablemente constituidas con el solo mérito de las comunicaciones electrónicas que la sociedad administradora realice por cuenta de los participantes a la empresa de depósito de valores, quien no tendrá responsabilidad por las anotaciones que se realizaren en virtud de lo dispuesto en este inciso. Estas prendas solo podrán ser alzadas por la sociedad administradora, de acuerdo al procedimiento anterior, o por resolución judicial ejecutoriada".

El inciso $1^{\circ}$, como se ve, establece un deber para las sociedades (anónimas) administradoras de la liquidación y compensación de instrumentos financieros ${ }^{56}$, en orden a exigir "garantías" a los participantes en el sistema ${ }^{57}$, destinadas a asegurar el cumplimiento de las obligaciones asumidas por su participación en el sistema y, en especial, por aquellas derivadas de la emisión de "ordenes de compensación".

Como la norma precedente habla en general de "garantías", resulta posible que en principio ellas sean de cualquier clase; pero el inciso $2^{\circ}$ del artículo 26 deja librado a las "normas de funcionamiento" 58 el punto de qué tipos específicos de garantía puedan ser exigidos (lo mismo que su cobertura y el momento de su constitución).

El inciso $4^{\circ}$ supone que las normas de funcionamiento hayan establecido (e implícitamente las autoriza para establecerla), como garantía específica, la consistente en una

\footnotetext{
55 DO. de 14 de mayo de 2009.,

56 Tratadas en el capítulo $1^{\circ}$ del título $2^{\circ}$ de la ley (artículos 3 a 11 ).

57 Según el artículo 21 de la ley, son participantes en el sistema de liquidación y compensación los agentes de valores, los corredores de bolsas de valores, los corredores de bolsas de productos, los bancos y las "demás personas que autorice la Superintendencia [de Valores y Seguros] a través de normas de carácter general”.

58 Ellas deben ser elaboradas por las sociedades administradores y aprobadas, previo acuerdo favorable del Consejo del Banco Central, por la Superintendencia de Valores y Seguros. El régimen de tales normas está en los artículos 7 a 10 de la ley.
} 
prenda de instrumentos financieros guardados en una empresa de depósito y custodia de valores. Como sabemos, de acuerdo con las reglas generales, tales instrumentos pueden ser titulados o bien desmaterializados. Ahora bien, el inciso $4^{\circ}$ en primer lugar reenvía la constitución, la modificación y el alzamiento de las prenda de esos valores (a las cuales se refiere con la expresión: "dichas garantias") al artículo 14 de la Ley $\mathrm{N}^{\circ}$ 18.876; pero acto seguido ofrece él mismo una forma de constituir la prenda ("Las prendas se entenderán irrevocablemente constituidas [...]"). Por otra parte, si se examina el artículo 14 de la última ley citada, ahí no se encuentran normas sobre constitución, modificación y alzamiento de prendas (y otros derechos reales) más que en los incisos $7^{\circ}, 8^{\circ}$ y 9 , en los cuales se discurre sobre la base de anotaciones en cuenta ${ }^{59}$, y esto supone tratarse de valores desmaterializados. La contradicción e incongruencia resultan, por ende, ser aparentes cuando interpretamos que el reenvío genérico al artículo 14 es la regla especial para el caso de una prenda de valores desmaterializados, que entonces concretamente es a los incisos $7^{\circ}, 8^{\circ}$ y $9^{\circ}$ de ese artículo, porque en ellos precisamente se trata el caso ("Para constituir, alzar o modificar prendas [...] en un sistema de compensación y liquidación de instrumentos financieros [...]") ${ }^{60}$; mientras que la forma de constituir la garantía que se describe en el inciso $4^{\circ}$ es la regla general para la prenda de valores titulados o no desmaterializados que se encuentran, empero, en depósito.

2. Por consiguiente, cuando se trata de constituir prenda sobre valores destinada a asegurar las obligaciones de los participantes en el sistema de liquidación y compensación de instrumentos financieros, uno es el régimen si tales valores son titulados y otro cuando están desmaterializados. Aunque en este trabajo solo interese el segundo caso, expondremos ambos para entender mejor el complicado engarce de las normas involucradas.

a) Si la indicada prenda haya de recaer sobre valores titulados, la forma de constituirla viene indicada por el inciso $4^{\circ}$ mismo del artículo 26 de la Ley $\mathrm{N}^{\circ} 20.345$, en su segundo segmento. De acuerdo con este, la constitución tiene lugar ${ }^{61}$ por el solo mérito de la comunicación electrónica que la sociedad administradora perteneciente al sistema de liquidación y compensación dirija, por cuenta del participante (o sea, del agente, corredor o banco que celebró la operación y emitió la orden de compensación), a la empresa de depósito de valores en que se encuentran guardados los instrumentos financieros que se trata de pignorar.

La ley supone, empero, que la sociedad de custodia de todos modos debe hacer una anotación prendaria, como es que la exime de toda responsabilidad "por las anotaciones que se realizaren en virtud de lo dispuesto en este inciso", o sea, precisamente del inciso $4^{\circ}$.

\footnotetext{
${ }^{59}$ Artículo 14 inciso $7^{\circ}$ de la Ley $\mathrm{N}^{\circ} 18.876$ : "Con el solo mérito de tal solicitud, la empresa efectuará una anotación en cuenta [...]"; inciso $8^{\circ}$ : "Las anotaciones que la empresa realice [...]".

${ }^{60}$ Se tendrá presente que los incisos $7^{\circ}, 8^{\circ}$ y $9^{\circ}$ fueron incorporados en el artículo 14 de la Ley $\mathrm{N}^{\circ} 18.876$ precisamente por la Ley $\mathrm{N}^{\circ} 20.345$, que creó el sistema de compensación y liquidación de instrumentos financieros (artículo $46 \mathrm{~N}^{\circ} 3$ ).

61 "Irrevocablemente" dice la disposición, lo cual es aclarado por el artículo 27 de la Ley $\mathrm{N}^{\circ} 20.345$.
} 
El segmento final del inciso $4^{\circ}$ expresa: "Estas prendas solo podrán ser alzadas por la sociedad administradora, de acuerdo al procedimiento anterior, o por resolución judicial ejecutoriada". El alzamiento, pues, también tiene lugar "con el solo mérito de las comunicaciones electrónicas que la sociedad administradora realice por cuenta de los participantes a la empresa de depósito de valores, quien no tendrá responsabilidad por las anotaciones que se realizaren en virtud de lo dispuesto en este inciso". Como siempre acaece, la modificación de una prenda ya constituida debe ser operada del mismo modo en que es constituida.

Una resolución judicial firme puede disponer el alzamiento de la prenda, lo cual procede si la prenda se extinguió por los medios principales o derivativos generales por los cuales se extingue toda prenda y la sociedad de depósito se negó a ejecutarlo.

b) Si, en cambio, la prenda de que tratamos deba recaer sobre valores desmaterializados -y ahora es el caso que interesa en este trabajo-, su constitución, y también la modificación y el alzamiento, quedan regidos por el inciso $7^{\circ}$ del artículo 14 de la Ley $\mathrm{N}^{\circ}$ 18.876: "Para constituir, alzar o modificar prendas o derechos reales en un sistema de compensación y liquidación de instrumentos financieros, la sociedad administradora del sistema enviará una solicitud a la empresa por cuenta de los participantes a cuyo nombre se encuentren depositados los valores de que se trate. Con el solo mérito de tal solicitud, la empresa efectuará una anotación en cuenta que, de conformidad al reglamento interno, refleje la constitución, modificación o alzamiento de la prenda o derecho real sobre los valores respectivos, y a partir de ese momento se entenderán constituidos tales derechos para todos los efectos legales. Las garantías asi constituidas se regirán por el Titulo XXII de la ley $N^{o}$ 18.045, aun cuando se trate de prendas sin desplazamiento". La sociedad administradora, pues, por cuenta del participante en el sistema, debe enviar una solicitud a la sociedad de depósito, en donde se encuentran anotados en cuenta los valores de ese participantes, que se trata de pignorar. Con el solo mérito de esta solicitud, la empresa de depósito debe anotar en cuenta la pignoración de los valores. Esta anotación los constituye en prenda. También se aplican los incisos $8^{\circ}$ y $9^{\circ 62}$.

El último segmento de la norma sujeta la garantía al título $22^{\circ}$ de la Ley $\mathrm{N}^{\circ}$ 18.045, constituidos por los artículos 173 a 178. Todos ellos, menos el 173, son aplicables a la prenda de valores anotados en cuenta, porque nada de su generalidad autoriza la exclusión, como sí acaece en el mencionado artículo 173, porque atañe a prendas sobre muebles corporales o sobre títulos de crédito no depositados, en todos los casos, pues, con entrega de la cosa o del título, lo cual es incompatible con la prenda de valores desmaterializados de que tratamos.

\footnotetext{
62 Artículo 14 inciso $8^{\circ}$ de la Ley $\mathrm{N}^{\circ}$ 18.876: "Las anotaciones que la empresa realice de conformidad a lo señalado en el inciso anterior podrán ser realizadas por cuenta del depositante, o bien, de sus mandantes, en las cuentas identificadas a nombre de estos, según lo indique el depositante. Para efectos de constituir, modificar o alzar válidamente prendas $u$ otros derechos reales por cuenta de estos últimos, el depositante deberá contar con una autorización general o especial dada por sus mandantes para proceder en tal sentido". Inciso 9": " $L a$ empresa, a solicitud de cualquier interesado, deberá certificar la constitución de los derechos referidos en este articulo, especificando los valores sobre los cuales recayeren, la fecha en que hubieren sido constituidos, el titular de los valores respectivos, así como el derecho de que se tratare".
} 
c) En el resto, todas las garantías destinadas a asegurar las obligaciones de los participantes en el sistema de liquidación y compensación de instrumentos financieros y, por ende, también aquellas que recaen sobre valores desmaterializados, quedan sometidas al régimen previsto en el capítulo $1^{\circ}$ del título $4^{\circ}$ de la Ley $\mathrm{N}^{\circ} 20.345$, que se inicia con el artículo 26 -con el cual iniciamos esta exposición-y llega hasta el 29.

\section{EL ARTíCULO 20 DEL "REGLAMENTO DEL REGISTRO DE PRENDAS SIN DESPLAZAMIENTO"}

En fin, conviene examinar el artículo 20 del Reglamento del Registro de Prenda sin Desplazamiento, que establece una norma de distribución de las maneras de celebrar prendas, en cuanto afecta a la que es objeto del presente estudio y que, en todo caso, puede desorientar. Dice ella: "Las prendas que se perfeccionen conforme a la Ley $N^{o}$ 18.876, que establece el marco legal paro la constitución y operación de entidades privadas de depósito y custodia de valores, o conforme a la Ley $N^{\circ} 20.345$, sobre sistemas de compensación y liquidación de instrumentos financieros, se sujetarán a las disposiciones de las leyes referidas./ [Inciso $2^{\circ}$ ] Las prendas que se constituyan de conformidad al Titulo XXII de la Ley $N^{o}$ 18.045, de Mercado de Valores, se sujetarán a las disposiciones de dicha ley".

a) La Ley $\mathrm{N}^{\circ}$ 18.876, que: Establece el marco legal para la constitución y operación de entidades privadas de depósito y custodia de valores, en su artículo 14 (y en el 13), en efecto, regula la constitución de prendas sobre valores depositados en una empresa de depósito de tales, en la forma que examinamos en su momento. Ese depósito puede ser físico de un título, o registral consistente en una anotación en cuenta. En ambos casos se los puede pignorar sin desplazamiento de acuerdo con la nueva ley, según sus reglas generales cuando hay un título físico y según su artículo 8 que lo autoriza expresa y directamente cuando hubo una anotación en cuenta (cuyo inciso $2^{\circ}$, por lo demás, se remite a la citada Ley $\mathrm{N}^{\circ}$ 18.876); y en ambos casos, además, se debe dar cumplimiento a lo dispuesto en los citados artículos 13 y 14 de la Ley $\mathrm{N}^{\circ} 18.876$ (como ha sido explicado más atrás). Ahora bien, el artículo 20 del Reglamento da la sensación de decir que una prenda atenida a la Ley $\mathrm{N}^{\circ}$ 18.876 solo se sujetará a las disposiciones de esa ley y no a las de la nueva sobre prenda sin desplazamiento. Pero no puede ser así, porque tal implicaría que el Reglamento ha derogado los términos explícitos del artículo 8 de la nueva ley, que sí autorizan la pignoración de valores desmaterializados. La única interpretación posible es, pues, la dicha, en orden a que tal pignoración se rige por ambas leyes.

b) La Ley No 20.345, sobre Sistema de compensación y liquidación de instrumentos financieros, en sus artículos 26 a 29 regula las garantías que los participantes en el sistema de liquidación y compensación deben otorgar a sus sociedades administradoras, para asegurar el cumplimiento de las obligaciones asumidas por ellos o que se deriven del ingreso de órdenes de compensación (artículo 26). La norma habla, muy en general, de "garantías" y, como vimos, abandona a las "normas de funcionamiento" la determinación de su consistencia o tipo, el monto garantizado y la oportunidad de su realización (artículos 26 inciso $2^{\circ}$ y $7 \mathrm{~N}^{\circ} 8$ ). Por consiguiente, la garantía que se fije puede consistir o no en valores depositados en una empresa de depósito de tales, y el depósito, a su vez, 
puede ser físico, de títulos, o registral mediante la anotación del valor en cuenta. Si la prenda que se fije es sobre valores anotados en cuenta, las normas aplicables son el artículo 8 de la nueva ley, el inciso $2^{\circ}$ del artículo 26 de la Ley $\mathrm{N}^{\circ} 20.345$ y el artículo 14 incisos $7^{\circ}, 8^{\circ}$ y $9^{\circ}$ de la Ley $\mathrm{N}^{\circ} 18.876$ más el título $22^{\circ}$ de la Ley $\mathrm{N}^{\circ} 18.045$ (por mandato del inciso $7^{\circ}$ del artículo 14 de la Ley $\mathrm{N}^{\circ}$ 18.876). Pero cuando el artículo 20 del Reglamento expresa que las prendas que se perfeccionen [...] conforme a la Ley $N^{o}$ 20.345, sobre sistemas de compensación y liquidación de instrumentos financieros, se sujetarán a las disposiciones" de esta misma ley, nuevamente aparenta disponer que solo se sujetarán a las disposiciones de la Ley $\mathrm{N}^{\circ} 18.876$ y no a las del artículo 8 la nueva (ni a las de la Ley $\mathrm{N}^{\circ} 20.345$ y de la Ley $\left.\mathrm{N}^{\circ} 18.045\right)$; lo cual no pudo realmente decir, porque eso implicaría la derogación reglamentaria de una norma legal.

c) En el título $22^{\circ}$ de la Ley $\mathrm{N}^{\circ} 18.045$ (artículos 173-178, que, en realidad, contienen las reglas a que deben ceñirse las prendas indicadas en el artículo 30 de la ley) se regulan las prendas que pueden recaer sobre una serie de objetos señalados en el artículo 173 (valores de oferta pública, monedas, oro, plata u otros valores de crédito), destinadas a caucionar las obligaciones de los corredores de bolsa entre sí, o con las bolsas de valores, o con sus clientes, o de cualquiera de ellos para con aquellos, por operaciones de corretaje o por actividades complementarias. En el articulado no se mencionan ni la prenda sin desplazamiento en general ni la de valores anotados en cuenta, en especial; por ende, la ley no ofrece reglas concernientes. Así que cuando el inciso $2^{\circ}$ del artículo 20 del Reglamento expresa: "Las prendas que se constituyan de conformidad al Título XXII de la Ley No 18.045, de Mercado de Valores, se sujetarán a las disposiciones de dicha ley”, dice algo muy verdadero, pero que, por la razón dicha, no viene al caso. Ahora bien, no debe dudarse que si la garantía que ofrezca un corredor a terceros ante los cuales responde o un cliente al corredor consistiera en valores anotados en cuenta, esa prenda queda regida por los artículos 8 de la nueva ley y 14 de la Ley $N^{\circ} 18.876$.

En tales circunstancias, el artículo 20 del Reglamento no es muy oportuno.

\section{BIBLIOGRAFÍA}

\section{LITERATURA}

CAllegari, Mia (2004), Il pegno su titoli dematerializzati (Milano, Giuffrè).

Caballero Germain, Guillermo (2010), La adquisición "a non domino" de valores anotados en cuenta (Madrid, Civitas).

CamaCho Clavijo, Sandra (2003), La prenda de valores anotados en cuenta: constitución y efectos (Valencia, Tirant Lo Blanch).

CORTÉS GARCÍA, Eduardo (2002), La desmaterialización de los titulos-valores (Valladolid, Lex Nova).

Díaz Moreno, Alberto (1991), "La prenda de anotaciones en cuenta", en Revista Crítica de Derecho Inmobiliario, 603 (Madrid, marzo-abril).

GAYO, Institutiones.

GUZMÁN BRITO, Alejandro (2004), Derecho privado romano (Santiago, Editorial Jurídica de Chile, $4^{\text {a }}$ reimpresión), II. 
GUZMÁn BRITO, Alejandro (2010), "El derecho real de prenda sin desplazamiento", en Revista de Derecho de la Pontificia Universidad Católica de Valparaiso, vol. 34, $1^{\mathrm{er}}$ semestre (Valparaíso).

GUZMÁN BRITO, Alejandro (2009), "El llamado contrato de prenda sin desplazamiento", en Revista Chilena de Derecho Privado "Fernando Fueyo Laneri", vol. 13 (Santiago).

GUZMÁN BRITO, Alejandro (2008), "Las prendas ordinaria y sin desplazamiento de la Ley No 20.190 recaídas en cosa ajena”, en: MANTILla ESPINOZA, Fabricio - PIZARRO WILSON, Carlos (coordinadores), Estudios de Derecho privado en homenaje a Christian Larroumet (Santiago de Chile - Bogotá, Fundación Fernando Fueyo - Universidad Diego Portales - Universidad del Rosario).

\section{FUENTES}

Código Civil de Chile.

Decreto-ley No 1.263: Orgánico de la administración financiera del Estado, publicado en el DO. de 28 de noviembre de 1975.

Decreto-ley No 3.500, de 1980: Que establece un nuevo sistema de pensiones, publicado en $D O$. de 13 de noviembre de 1980.

“Ley de prenda sin desplazamiento", contenida en el artículo 14 de la Ley No 20.190 [ver].

Ley No 24: Del Mercado de Valores, de 28 de julio de 1988, de España.

Ley No 4.287: Sobre prenda de valores mobiliarios a favor de los bancos, publicada en DO. de 23 y 29 de febrero de 1928.

Ley No 18.045: De mercado de valores, publicada en DO. de 22 de octubre de 1981.

Ley No 18.046: Sobre sociedades anónimas, publicada en DO. de 22 de octubre de 1981.

Ley No 18.112: Dicta normas sobre prenda sin desplazamiento, publicada en DO. de 16 de abril de 1982 .

Ley No 18.876: Establece el marco legal para la constitución y operación de entidades privadas de depósito y custodia de valores, publicada en DO. de 21 de diciembre de 1989.

Ley No 19.623, publicada en DO. de 26 de agosto de 1999.

Ley No 20.190: Introduce adecuaciones tributarias e institucionales para el fomento de la industria de capital de riesgo y continua el proceso de modernización del mercado de capitales, publicada en DO. de 5 de junio de 2007.

Ley No 20.382, publicada en el DO. de 20 de octubre de 1989.

Reglamento de la Ley No 18.876 sobre depósitos de valores, aprobado por Decreto supremo No 734, del Ministerio de Hacienda, publicado en el DO. de 30 de noviembre de 1991.

Reglamento de sociedades anónimas, aprobado por el Decreto supremo No 568, del Ministerio de Hacienda, de 1982, publicado en DO. de 13 de noviembre de 1982.

Reglamento del Registro de Prendas sin Desplazamiento, contenido en el Decreto supremo $\mathrm{N}^{\circ} 722$ del Ministerio de Justicia, publicado en el DO. de 23 de octubre de 2010. 